\title{
Comparative Isotope Hydrology Study of Groundwater Sources and Transport in the Three Cascade Volcanoes of Northern California
}

\author{
M.L. Davisson \\ T.P. Rose
}

September 1997

This is an informal report intended primarily for internal or limited external distribution. The opinions and conclusions stated are those of the author and may or may not be those of the Laboratory.

Work performed under the auspices of the U.S. Department of Energy by the Lawrence Livermore National Laboratory under Contract W-7405-Eng-48. 


\section{DISCLAIMER}

This document was prepared as an account of work sponsored by an agency of the United States Government. Neither the United States Government nor the University of California nor any of their employees, makes any warranty, express or implied, or assumes any legal liability or responsibility for the accuracy, completeness, or usefulness of any information, apparatus, product, or process disclosed, or represents that its use would not infringe privately owned rights. Reference herein to any specific commercial product, process, or service by trade name, trademark, manufacturer, or otherwise, does not necessarily constitute or imply its endorsement, recommendation, or favoring by the United States Government or the University of California. The views and opinions of authors expressed herein do not necessarily state or reflect those of the United States Government or the University of California, and shall not be used for advertising or product endorsement purposes.

This report has been reproduced directly from the best available copy.

Available to DOE and DOE contractors from the

Office of Scientific and Technical Information

P.O. Box 62, Oak Ridge, TN 37831

Prices available from (423) 576-8401

Available to the public from the

National Technical Information Service

U.S. Department of Commerce

5285 Port Royal Rd.,

Springfield, VA 22161 


\title{
Comparative Isotope Hydrology Study of Groundwater Sources and Transport in the Three Cascade Volcanoes of Northern California
}

\author{
M.L. Davisson and T.P. Rose \\ Isotope Sciences Division \\ Lawrence Livermore National Laboratory \\ P.O. Box 808 L-231 \\ Livermore, CA 94550
}

\begin{abstract}
Quaternary-age volcanic peaks of Mt. Lassen, Mt. Shasta, and Medicine Lake Volcano preferentially recharge and transport large volumes of annual precipitation into mega-scale channels hosted in underlying volcanic layers. At the terminus of laterally extensive lava flows, or in deep incisions of these layers, groundwater emerges as large volume cold springs. The combined discharge of these springs contributes half the annual storage capacity of Shasta Reservoir, and is utilized to generate 2000 gigawatts of hydroelectric power each year. Moreover, the springs provide a natural habitat for many rare and endangered species. In the Hat Creek Valley, located north of Mt. Lassen, Rose et al. (1996) showed that the low $\delta^{18} \mathrm{O}$ discharge of large volume springs at Rising River and Crystal Lake originates from snow melt in the high elevation, high precipitation region surrounding Lassen Peak. Groundwater transport in this basin is enhanced by the occurrence of the Quaternary Hat Creek basalt flow, which extends nearly the entire length of Hat Creek Valley. In contrast, the $\delta^{18} \mathrm{O}$ values of large-volume springs that discharge in the Mt. Shasta region indicate a larger percentage of local recharge at lower elevations since the high elevation snow melt on the volcano is depleted by $>1$ per mil relative to the largest springs. The $\delta^{18} \mathrm{O}$ value of the Fall River Springs (FRS) system is similar to small springs that occur at high elevations on Medicine Lake Volcano. The large volume of the FRS discharge coupled with a lack of surficial drainages in this area indicates that a large percentage of the annual precipitation over an $\sim 750 \mathrm{mi}^{2}$ area of the Medicine Lake volcanic plateau goes to recharge the FRS aquifer system. Groundwater transport to the FRS is enhanced by the occurrence of the $10 \mathrm{kyr}$ Giant Crater lava flow, a single geologic unit that extends from the base of Medicine Lake Volcano to the FRS.
\end{abstract}


Dissolved magmatic $\mathrm{CO}_{2}$ derived from the Quaternary volcanic centers is observed in many of the large volume springs in the southern Cascade Range. For example, the radiocarbon concentration in Rising River Springs is 80 pmc, which indicates at least $20 \%$ of its dissolved inorganic carbon is derived from a magmatic source in the Lassen region. The radiocarbon activity in the FRS is as low as 73 pmc, indicating a minimum contribution of $27 \%$ magmatic $\mathrm{CO}_{2}$ from Medicine Lake volcano. Magmatic $\mathrm{CO}_{2}$ fluxes in the Shasta region are highest around the base of the volcano, where low-volume, $\mathrm{CO}_{2}$-rich, ${ }^{14} \mathrm{C}$-absent soda springs occur. Relatively large quantities of magmatic $\mathrm{CO}_{2}$ are observed in the Big Springs of the McCloud River, which have a $\delta^{18} \mathrm{O}$ signature consistent with low elevation recharge in the Shasta region.

Differences in the isotopic characteristics of the major spring systems at Mt. Shasta relative to Mt. Lassen and Medicine Lake Volcano reflect significant differences in the geomorphology of the volcanoes. In particular, the composite nature of the Shasta stratocone tends to limit the depth of groundwater recharge, confining the majority of groundwater flow to the shallowest layers, which tend to be of more local extent. The lower permeability of the composite cone also acts as a trap for magmatic $\mathrm{CO}_{2}$ emissions, generally limiting the gas discharge to localized fracture zones at lower elevations. At Mt. Lassen and Medicine Lake Volcano, groundwater recharge occurs primarily at high elevations, along vertical fracture systems with high permeabilities. These features, combined with laterally extensive basalt flows, act to focus groundwater transport deeper and over longer lateral distances. The magmatic $\mathrm{CO}_{2}$ dissolution process probably occurs in close proximity to the geothermal systems at Lassen and Medicine Lake, where $\mathrm{CO}_{2}$ gas escaping along deep fractures encounters downward percolating groundwater.

\section{INTRODUCTION}

The landscape of northeastern California is dominated by the three Quaternary-age volcanic centers of Mt. Lassen, Mt. Shasta, and Medicine Lake Volcano (Fig. 1). Dotting the landscape around these volcanic centers are some of the largest volume springs in the United States (Meinzer, 1927). These springs, whose combined flow nearly equals 3000 cubic feet per second (cfs), provide virtually all of the base flow component to the Upper Sacramento, McCloud, and Pit Rivers. In addition, the spring flow supplies nearly half of the 4.6 million acre-ft storage capacity of Lake Shasta each year, and is utilized in hydroelectric power generators along the Pit River and Hat Creek to produce >2000 
gigawatts of power annually (Bowers, personal communication). The discharge areas of these springs have created a unique natural wetland habitat for several rare aquatic species, some of which are listed as endangered or threatened species (Ellis, 1997).

The large volume springs characteristically discharge at the terminus of Quaternary lava flows, or along deep erosional incisions in these flows. The large discharge rates and cold temperatures $\left(<12^{\circ} \mathrm{C}\right)$ of the springs, coupled with observed seasonal fluctuations in their flow rates, requires relatively shallow aquifer systems (generally $<1000$ feet deep) that are annually recharged by high elevation snow melt (Rose et al., 1996; Manga, 1997). In addition, the dissolved inorganic carbon in many of these springs shows isotopic evidence for the incorporation of significant amounts of magmatic $\mathrm{CO}_{2}$ derived from nearby volcanic centers (Rose and Davisson, 1996).

This report presents new isotopic data for spring waters and surface runoff originating from recharge areas in the Cascade Range of northern California. These data provide insight into the recharge and flow characteristics of the groundwater systems that supply the large volume springs. Comparison of the flow systems around the three main volcanic centers (Shasta, Lassen and Medicine Lake) provides strong evidence that the groundwater flow system in the Medicine Lake area is remarkably similar to that of the Hat Creek Basin system described by Rose et al. (1996). Moreover, isotopic data for groundwaters in the Fall River-Medicine Lake region reveals a strong connection between recharge areas on Medicine Lake volcano and the discharge at the Fall River Springs.

\section{HYDROGEOLOGIC SETTING}

Although the Mt. Lassen, Mt. Shasta, and Medicine Lake volcanoes are all associated with the same volcanic arc complex (e.g. Christiansen, 1982), their surface expressions are highly distinct from one another. These morphological differences play a significant role in in determining how groundwater is transported in each system. Mt. Shasta is an andesitedacite stratovolcano that was constructed in four brief eruptive episodes over the past 450 
ka, with extended pauses dominated by erosion. As a result, the surficial geologic landscape of Shasta is characterized by numerous fragmented volcanic deposits (Christiansen, 1982) wherein continuous volcanic layers are limited in aerial extent (Fig. 1). The largest springs in the Mt. Shasta region occur at Big Springs (>700 cfs), which discharge in the canyon of the upper McCloud River. Several large springs also occur along the upper Sacramento River canyon. In each case, these springs emanate from lava flows that were exposed by deep erosional incision along river channels. In addition, numerous smaller springs dot the lower reaches of Mt. Shasta, emerging from the erosional remnants of the dissected lava flows that comprise the stratocone.

The Lassen Volcanic Center contains hundreds of small- to intermediate-volume eruptive centers of mostly mafic composition that surround a few larger volume intermediate- to silicic-volcanic centers (e.g. Clynne, 1990). Lassen Peak itself is a large dacitic dome that rests on the erosional remnants of an older stratocone. Just north of Lassen Peak is the Hat Creek Valley, a graben-like feature bounded by northwest-trending normal faults (Muffler et. al., 1994). The floor of Hat Creek Valley is covered by the 15 kyr Hat Creek Basalt flow, which extends from an eruptive center near the base of Mt. Lassen northward for a distance of $\sim 30 \mathrm{~km}$. This unit is in turn underlain by a thick sequence of older basaltic and andesitic deposits that are locally exposed along the fault scarp of the Hat Creek Rim. Rising River Springs emerge at the terminus of the Hat Creek Basalt flow with a historical average flow rate of $300 \mathrm{cfs}$. Crystal Lake, a spring-fed lake located a few kilometers NW of Rising River, discharges an additional $100 \mathrm{cfs}$ from the older lava flows underlying the Hat Creek basalt.

Medicine Lake Volcano is a broad shield volcano with a shallow caldera located near its crest. It comprises mostly basaltic to andesitic deposits, with more recent silicic volcanic deposits limited to high elevations on the volcano (Christiansen, 1982). The summit area is underlain by a young rhyolitic intrusion. The Giant Crater lava field consists of a series of laterally extensive $10.5 \mathrm{kyr}$ basalt flows (Donnelly-Nolan et. al., 1991) that stretch from 
the southern flank of the volcano southward for a distance of $40 \mathrm{~km}$ (Fig. 1). Both Medicine Lake Volcano and the Giant Crater lava field have virtually no surface water drainages, even during the springtime melting of the snowcap. As a result, the largest spring group in California emerges along a $10 \mathrm{~km}$ wide belt at the terminus of the Giant Crater lava field. This series of springs combine to form the $\sim 1200 \mathrm{cfs}$ flow of the Fall River.

It is notable that both the Lassen Volcanic Center and Medicine Lake Volcano are underlain by relatively shallow geothermal systems (Muffler et al., 1982; Evans and Zucca, 1988). However, whereas the Lassen geothermal system has numerous surface expressions of geothermal activity, the Medicine Lake geothermal system is relatively tightly sealed.

\section{$\underline{\text { Regional Precipitation Patterns and their Influence on Spring Discharge }}$}

Precipitation rates are highest at high elevation peaks in northern California (see Fig. 3; data from Rantz, 1969). Lassen Peak averages around 90 inches of rainfall equivalent per year, mostly as accumulated snow. Mt. Shasta and Medicine Lake Volcano also have local maximums that average 70 and 40 inches per year, respectively. In the Shasta area, annual precipitation rates of up to 80 inches per year occur at lower elevations south of Shasta Peak. Likewise, local maximums also occur in the Clover Mtn. area (90 inches) on the west side of Hat Creek Valley. Rain shadows occur on the back side of each of the volcanic peaks, where annual precipitation rates can drop as low as 15 inches per year.

Large volume spring discharge rates in the Hat Creek Valley are variable in time and have been shown to have direct and near-immediate links to precipitation rates in their recharge areas (see Manga, 1997). For example, Rose et al. (1996) showed that Rising River and Crystal Lake springs decreased in flow as much as $\sim 50 \%$ during the drought of 1987 to 1992 , which was approximately equivalent to the decrease in the annual snow pack during that time (Fig. 2). A 50\% decrease in flow from the Fall River Springs is also 
reported to have occurred in response to the 1987-1992 drought (Bowers, personal communication).

\section{METHODS}

The $\delta^{18} \mathrm{O}$ and $\delta \mathrm{D}$ values of groundwater provide useful indicators of recharge and flow patterns in the Sierra Nevada and southern Cascade Ranges. The isotopic composition of precipitation varies as a function of elevation and distance from the ocean (Dansgaard, 1964; Smith et. al., 1979). In regions where topographic variations are large, such as the southern Cascades, groundwater that originates from high elevation recharge is readily distinguishable from lower elevation recharge, and regional groundwater flow systems can be distinguished from localized systems (e.g. Rose et al., 1996).

Water samples were collected throughout the study area in small glass bottles with airtight caps to prevent evaporation. The samples were analyzed for their ${ }^{18} \mathrm{O} /{ }^{16} \mathrm{O}$ and deuterium/hydrogen $(\mathrm{D} / \mathrm{H})$ ratios, respectively, using the water equilibration method (Epstein and Mayeda, 1953) and the zinc reduction technique (Coleman et. al., 1982). Isotopic analyses were performed on a VG Prism isotope ratio mass spectrometer. The results of all stable isotope analyses are reported in the usual delta notation where

$$
\delta=\left(\frac{R_{s a}}{R_{\text {std }}}-1\right) 1000
$$

$R_{s a}$ is the isotopic ratio of the sample, and $R_{s t d}$ is the isotopic ratio of a standard, which in this case is either Standard Mean Ocean Water for the $\delta \mathrm{D}$ and $\delta^{18} \mathrm{O}$ (Craig, 1961a), or Pee Dee Belemnite for the $\delta^{13} \mathrm{C}$. Reproducibility is \pm 0.1 per mil for $\delta^{18} \mathrm{O}$ and \pm 1.0 per mil for $\delta \mathrm{D}$.

Radiocarbon has been used as a groundwater dating tool for decades (see Fontes, 1994). In the Cascade groundwater systems, however, aquifer residence times are too short to 
incur any significant decay (half life $=5730$ years) in radiocarbon concentrations (see Rose et al., 1996 and Rose and Davisson, 1996). Nevertheless, radiocarbon concentrations have been used effectively to trace the interaction of regional groundwater with radiocarbon-depleted magmatic $\mathrm{CO}_{2}$ (Rose and Davisson, 1996). Furthermore, dual analyses of the stable ${ }^{13} \mathrm{C}$ and radiocarbon of dissolved inorganic carbon in these waters provides a means to graphically distinguish different sources of carbon.

Carbon isotope samples were collected in 125 or $250 \mathrm{ml}$ amber glass bottles with a 1/8" septa cap, poisoned with a few drops of saturated $\mathrm{HgCl}_{2}$ solution, and stored refrigerated no more than one month. The dissolved inorganic carbon is converted to $\mathrm{CO}_{2}$ gas by acidification with orthophosphoric acid, liberated under vacuum using an ultrapure carrier gas, and trapped cryogenically (McNichol et. al., 1994; Davisson and Velsko, 1994). The $\mathrm{CO}_{2}$ sample is then split, and one aliquot is measured for its $\delta^{13} \mathrm{C}$ value on the VG Prism while the other is converted to graphite at $570^{\circ} \mathrm{C}$ under closed conditions using $\mathrm{H}_{2}$ gas in the presence of a cobalt catalyst. The graphite is loaded into an aluminum target and analyzed for its radiocarbon content on the accelerator mass spectrometer at LLNL. The results are reported in percent modern carbon $(\mathrm{pmc})$, that results from a normalization to a pre-1950 atmospheric radiocarbon standard. Analytical reproducibility is \pm 0.2 per mil for $\delta^{13} \mathrm{C}$ and $\pm 1.0 \mathrm{pmc}$ for radiocarbon.

\section{RESULTS}

\section{Mt. Lassen and the Hat Creek Valley}

Stable isotope and radiocarbon values were measured for large and small volume spring discharges, thermal springs, and surface water samples collected throughout the LassenHat Creek region (see Table 1). Rose et al. (1996) showed that the large volume spring discharges at Rising River and Crystal Lake (Fig. 4a) had distinctly lower $\delta^{18} \mathrm{O}$ values (Fig. 4b) than low volume springs from the same area (Fig. 4c). The low volume springs 
throughout the Lassen-Hat Creek region reflect regional $\delta^{18} \mathrm{O}$ variations in precipitation that result from rain-out effects during storm track migration from west to east across the Sierra Nevada Range (e.g. Smith et. al., 1979; Ingraham and Taylor, 1991). Since the $\delta^{18}$ O values for Rising River and Crystal Lake were inconsistent with this regional isotopic pattern, it was determined that the only possible recharge area for these springs was the Lassen volcanic highlands (Fig. 4c). Specifically, the Lassen highlands were the only nearby location where the precipitation rates were high enough, and the $\delta^{18} \mathrm{O}$ values were low enough to provide a viable recharge area. The long-range $(45 \mathrm{~km})$ transport of groundwater from the Lassen region is structurally controlled by the Hat Creek Fault and the Hat Creek basalt flow, where the latter acts as a cap and shallow conduit for groundwater transport. The large volume springs emerge from the terminus of the Hat Creek basalt.

Radiocarbon measurements of groundwaters from this region are also useful for elucidating the regional flow pattern (Fig. 4d; see Rose et al., 1996; Rose and Davisson, 1996). Radiocarbon-absent magmatic $\mathrm{CO}_{2}$ emanating from the Lassen geothermal system is dissolved in groundwater and surface water in the Lassen Peak area, forming distinctive low- ${ }^{14} \mathrm{C}$ waters. Subsequent mixing with waters that contain dissolved inorganic carbon of biogenic or atmospheric origin yields distinctive mixing trends on a plot of ${ }^{14} \mathrm{C}$ versus $\delta^{13} \mathrm{C}$ (Fig. 5). The biogenic carbon end-member is fortuitously uniform due to 1) the common metabolic pathway of northern California vegetation, 2) high precipitation rates, and 3) the lack of carbonate minerals in the soil and rocks from this region. The carbon isotope data therefore provides a diagnostic tool for quantifying the amount of magmatic carbon that is dissolved in regional groundwaters. Estimates of dissolved magmatic $\mathrm{CO}_{2}$ fluxes in springs from the Lassen region are given in Rose and Davisson (1996). 


\section{Mt. Shasta Area}

Springs and surface waters were sampled at selected locations on the south and east sides of Mt. Shasta. Estimated discharge rates (in cfs) are given in Figure 6a, and analytical results are presented in Table 1. The largest springs in this region are the Big Springs (>700 cfs) which emanate from a deeply eroded escarpment in the upper McCloud River canyon, increasing the river flow a factor of 40 during baseflow. Shasta and Mossbrae Springs discharge under similar conditions in the upper Sacramento River valley, and combined with smaller spring flows such as Sisson Spring result in a river baseflow in excess of $200 \mathrm{cfs}$.

The $\delta^{18} \mathrm{O}$ values of springs and surface waters in the Mt. Shasta region range from -12.4 to -14.7 per mil (Fig. 6b). Surface runoff in Ash Creek has the lowest observed $\delta^{18} \mathrm{O}$ value $(-14.7 \%$ ) reflecting a source area at high elevations on the eastern side of Mt.

Shasta. Sisson Spring, located on the southwest side of the volcano, also has a $\delta^{18} \mathrm{O}$ value of $-14.7 \%$, indicating a similar high elevation source. The $\delta^{18} \mathrm{O}$ values of Big Springs $(-13.2 \% o)$ and Shasta Springs (-13.3\%o) indicate significant recharge contributions from lower elevations. In the case of Big Springs, the voluminous discharge (>700 cfs) requires a minimum of 55 inches $(140 \mathrm{~cm})$ of annual recharge over a $500 \mathrm{~km}^{2}$ area. The large volume of these springs probably requires contributions from both high and low elevation regions. The $\delta^{18} \mathrm{O}$ value of Big Springs may therefore represent a composite of high and low elevation recharge, suggesting the presence of both long and short range transport paths to the spring discharge point.

Using equations from Rose et al. (1996) that describe regional variations in $\delta^{18} \mathrm{O}$ as a function of elevation, we can estimate the recharge elevations and transport distances for some of the springs in the Shasta region. In the case of Sisson Spring, these equations predict a recharge elevation between $8300-9500$ feet. This is close to the altitude where Ash Creek originates (Fig. 6b). Therefore, the groundwater emerging from Sisson Spring probably migrated $\sim 10 \mathrm{~km}$ down a permeable layer that is essentially closed to interaction 
with lower elevation recharge. At Bear Spring, the recharge elevation is estimated to be $\sim 8200$ feet, suggesting a groundwater flowpath that is on the order of only $\sim 5 \mathrm{~km}$ in length. For the lower elevation, larger volume springs, the likelihood of integrated groundwater recharge at different elevations makes it difficult to estimate recharge elevations and transport distances. In the case of Big Spring, if a component of its recharge is derived from similar elevations as Sisson Spring, then a maximum transport distance of $\sim 20 \mathrm{~km}$ is possible. This length is still only half the distance determined for groundwater transport to Rising River and Crystal Lake in the Lassen-Hat Creek system.

Mt. Shasta is unique in comparison to the other two volcanic centers in that $\mathrm{CO}_{2}$-rich cold springs with low discharge rates occur along the base of the volcano (Fig. 6a). These $\mathrm{CO}_{2}$-rich springs include Shasta Soda Spring, which discharges low conductivity, low $\mathrm{pH}$ (4.5) water saturated with $\mathrm{CO}_{2}$ gas, and Warmcastle Soda Spring, which has a high conductivity, but is also charged with $\mathrm{CO}_{2}$ gas. The ${ }^{14} \mathrm{C}$ values of these soda springs are around 1 pmc, indicating a magmatic $\mathrm{CO}_{2}$ source. $\mathrm{CO}_{2}$-rich waters in the Lassen Region are limited to a few thermal springs associated with the high elevation, vapor-dominated portion of the Lassen geothermal system (Muffler et al., 1982). $\mathrm{CO}_{2}$-rich springs have not been reported in the Medicine Lake Volcanic area.

Radiocarbon concentrations of dissolved inorganic carbon in springs and surface waters from the Shasta region are heterogeneously distributed. Ash Creek and Bear Spring both have radiocarbon contents similar to modern atmosphere, while Sisson Spring and Mossbrae Spring have much lower ${ }^{14} \mathrm{C}$ values that reflect mixing with waters containing magmatic $\mathrm{CO}_{2}$. The relatively close proximity of Shasta Soda Spring to Mossbrae Spring undoubtedly influences the radiocarbon content of the latter spring. Big Spring has a radiocarbon concentration that suggests perhaps $10-20 \%$ of its dissolved inorganic carbon is derived from a magmatic source.

Rose and Davisson (1996) compared the carbon isotope values for springs and surface waters in the Shasta area to those in the Lassen region. In the Lassen highlands, the carbon 
isotopic composition of groundwater in the shallow subsurface is dominated by magmatic $\mathrm{CO}_{2}$ from the Lassen geothermal system. Two distinct magmatic carbon isotope endmembers are recognized, associated with two distinct processes: (1) the direct dissolution of magmatic $\mathrm{CO}_{2}$ gas, and (2) the equilibration of magmatic $\mathrm{CO}_{2}$ gas with dissolved inorganic carbon in the water to form a low- ${ }^{14} \mathrm{C}$ bicarbonate water. Subsequent mixing with atmospheric $\mathrm{CO}_{2}$ gas or biogenically-derived dissolved inorganic carbon yields the mixing arrays shown in Figure 5. At Mt. Shasta, magmatic $\mathrm{CO}_{2}$ in the shallow subsurface is observed only at lower elevations. This observation, coupled with the lack of geothermal activity at Shasta, indicates a significant difference in the way gases escape from these two volcanoes. Magmatic $\mathrm{CO}_{2}$ is incorporated into groundwater at Shasta only by the direct dissolution of gas escaping along fractures at low elevations, forming a single magmatic $\mathrm{CO}_{2}$ end-member in groundwater mixing processes (Figure 7). This implies that the majority of the magmatic $\mathrm{CO}_{2}$ beneath Shasta resides at depth, limiting the possibilities for interaction with shallow groundwaters.

\section{$\underline{\text { Medicine Lake Volcano Area }}$}

Large volume spring flow in the Medicine Lake region is limited to the Fall River Springs, located $\sim 40 \mathrm{~km}$ south of Medicine Lake Volcano. Between these features lies the Giant Crater lava field, which has virtually no springs or surface water features. The $\delta^{18} \mathrm{O}$ values of the Fall River Springs range from -13.3 to -13.6 per mil (Table 1 and Fig. 8a). Matching $\delta \mathrm{D}$ measurements for two of these samples indicate that the spring waters conform to the Global Meteoric Water Line (GMWL) of Craig (1961b), with no indication of significant evaporation. The $\delta^{18} \mathrm{O}$ values were also measured for several small volume springs located on Medicine Lake Volcano and in the surrounding Modoc Plateau region (see Table 1).

Small springs from the Medicine Lake highlands (Crystal, Schonchin and Paynes Springs) have $\delta^{18} \mathrm{O}$ values similar to the Fall River Springs. The small springs represent 
local groundwater recharge that follows shallow, localized flowpaths. Available $\delta \mathrm{D}$ data (Table 1) indicates that these springs also conform to the GMWL. The $\delta^{18} \mathrm{O}$ values for the small springs are consistent with the values predicted for recharge at an elevation of $\sim 7000$ feet using the $\delta^{18}$ O-elevation equations from Rose et al. (1996). Therefore, the $\delta^{18} \mathrm{O}$ values of water emerging from the Fall River Springs are consistent with recharge at a similar elevation.

However, closer inspection of the $\delta^{18} \mathrm{O}$ values for low volume springs located throughout the Medicine Lake region reveals that the $\delta^{18} \mathrm{O}$ values and spring elevations in this area are not consistent with the equations from Rose et al. (1996). Table 2 gives the $\delta^{18} \mathrm{O}$ values and elevations for several of these small springs, whose recharge areas are approximately the same elevation as their sampling elevation.

\section{Table 2. Low Volume Springs in the Medicine Lake Region}

$\begin{array}{lcc}\text { Sample } & \underline{\delta^{18} \mathrm{O}} & \underline{\text { Elevation }} \\ \text { Red Tank Spring } & -13.1 & 4760 \\ \text { Harris Spring } & -13.4 & 4900 \\ \text { Crystal Spring } & -13.7 & 6890 \\ \text { Schonchin Spring } & -13.7 & 6890 \\ \text { Payne Spring } & -13.8 & 6560\end{array}$

If we calculate the $\delta^{18} \mathrm{O}$-elevation slope expected for the two springs whose elevations and $\delta^{18} \mathrm{O}$ values have the greatest difference (i.e. Red Tank Spring and Crystal Spring), the resulting isotopic gradient is only -0.3 per mil per 1000 feet of elevation gained. This result is more than a factor of two lower than the gradients derived by Rose et al. (1996).

The low isotopic gradient for the Medicine Lake region is not surprising given the precipitation patterns in this area. Higher precipitation rates occur to the west, in the Mt. 
Shasta region, and to the south (Fig. 3). However, the Medicine Lake region lies in the rain-shadow of Mt. Shasta. Under these circumstances, most of the moisture carried by storm systems moving through this region is lost in elevation gains before it reaches the Medicine Lake area. This accounts for the relatively low mean annual precipitation rates (40 in/yr) at high elevations on Medicine Lake Volcano (Fig. 3).

We have highlighted the probability of reduced elevation effects on the $\delta^{18} \mathrm{O}$ values of precipitation in the Medicine Lake area in order to justify mass balance calculations reported in Rose et al. (1996). They suggested that in order to maintain the historical $\sim 1400 \mathrm{cfs}$ flow of the Fall River Springs, a mean annual recharge rate of 25 inches per year must occur over the $750 \mathrm{mi}^{2}$ volcanic plateau formed by Medicine Lake Volcano and the Giant Crater lava flow. If elevation effects dominated the $\delta^{18} \mathrm{O}$ variations in precipitation in this region, then the permissible recharge area for the Fall River Springs would be limited to a geographic area of only $\sim 250 \mathrm{mi}^{2}$. This would limit groundwater recharge to the highest elevation regions of Medicine Lake Volcano. However, the volcano does not receive a sufficient amount of annual precipitation to sustain all the Fall River Springs flow. It is likely, therefore, that $\delta^{18} \mathrm{O}$ variations in precipitation for the entire geographic area encompassing Medicine Lake Volcano and the Giant Crater lava field is no more than $~ 1.0$ per mil. This entire area must have enhanced permeability (fractures and lava tubes) that promotes the recharge of most of the annual precipitation and focuses groundwater transport south to the Fall River Springs. The paucity of springs and surface runoff in this region support this interpretation. Furthermore, if most of the annual precipitation on Medicine Lake Volcano goes to groundwater recharge, then approximately half the flow of the Fall River Springs is probably derived from the volcanic edifice.

Radiocarbon and $\delta^{13} \mathrm{C}$ measurements of low volume springs on Medicine Lake Volcano indicate that their dissolved inorganic carbon is derived from a modern biogenic source (Fig. 8b). However, radiocarbon measurements of the Fall River Springs indicate that at least $27 \%$ of its dissolved inorganic carbon is derived from a magmatic $\mathrm{CO}_{2}$ source. Given 
the known discharge rate, dissolved carbon concentration, and ${ }^{14} \mathrm{C}$ activity for the Fall River Springs, we are able to estimate the dissolved magmatic carbon flux carried by the springs. Assuming the fraction of dissolved magmatic carbon is $27 \%$ (a minimum value), we obtain a dissolved flux of $25 \times 10^{6} \mathrm{~kg} / \mathrm{yr}$ for the Fall River Springs. This is more than double the fluxes previously calculated for Lassen and Shasta volcanoes (Rose and Davisson, 1996). Such a large magmatic $\mathrm{CO}_{2}$ flux requires that the groundwater supplying flow to the Fall River Springs system must originate from a volcano where magmatic degassing is actively occurring. Given the hydrogeologic configuration of the Fall River aquifer system, it is clear that Medicine Lake Volcano is the only possible source of the magmatic $\mathrm{CO}_{2}$. Hence, the radiocarbon data independently confirms the Medicine Lake highlands as a significant recharge source for the Fall River Springs. Moreover, these data indicate that much of the annual recharge occurring on Medicine Lake Volcano must interact with a $\mathrm{CO}_{2}$ volatile phase derived from the geothermal system beneath the volcano.

\section{DISCUSSION}

The groundwater recharge and flow characteristics of the Fall River Springs system has many similarities to that of Rising River and Crystal Lake Springs in the Lassen region. Both spring flow systems have unusually high discharge rates that emerge from the toe of large Quaternary basalt flows. In both cases, recharge is derived from high elevation snow melt $\sim 40 \mathrm{~km}$ upgradient, and the dissolved inorganic carbon in these springs shows a significant magmatic $\mathrm{CO}_{2}$ component derived from volcanic emissions in the recharge area.

In the Mt. Shasta area, the large volume springs are not associated with broad, laterally continuous lava sheets, but rather they emerge in areas where erosion has cut into volcanic layers along the base of the stratocone. Groundwater transport distances are typically less than half that of the spring systems at Medicine Lake and Lassen. Magmatic $\mathrm{CO}_{2}$ emissions at Shasta appear to be limited to lower elevations, where low volume, $\mathrm{CO}_{2}$-rich soda springs are observed (Figure 9a). 
The nature of groundwater transport in these various systems is determined to a large extent by the geomorphology of the volcanic edifice, and by the continuity of the major lava flows that provide groundwater conduits. Recharge is greatly enhanced by the highly permeable nature of the volcanic rock, and by the presence of major fracture systems and lithologic discontinuities. The occurrence of silicic domes in all three volcanic centers provides an avenue of enhanced fracture permeability that may permit relatively deep transmission of groundwater recharge. At Medicine Lake volcano, vertical permeability may also be enhanced by the ring fracture system associated with the caldera.

At Lassen and Medicine Lake, lateral transport out of the volcanic highlands is greatly enhanced by the high permeability, laterally continuous Hat Creek and Giant Crater basaltic flows. These young lava beds contain large fractures and lava tubes (e.g. Evans, 1963) that promote the rapid lateral transport of groundwater. In the Lassen-Hat Creek system, groundwater flowing out of the Lassen highlands must drop in elevation around 3000 feet over a 9 mile lateral distance before it intersects the upper end of the Hat Creek basalt flow (Fig. 9b). A small portion of this flow actually arrives back at the surface as small volume spring flow on the volcanic highlands, forming the headwaters of Hat Creek. Given the volume of annual recharge, such a hydraulic gradient can only be maintained by rapid flow into hydraulic conduits with extremely high permeabilities, such as those found in the Hat Creek basalt flow.

Groundwater recharge on Medicine Lake volcano must be transported over a $\sim 5$ mile distance and a $~ 1500$ feet drop in elevation before it reaches the Giant Crater lava field. However, in this case, almost none of the annual recharge arrives back to the surface as spring flow. Additional recharge into the Giant Crater lava field must also occur south of the Medicine Lake volcano in order to maintain the flow rates in Fall River Springs.

It should be emphasized that groundwater emerging from the large volume springs does not show evidence for deep transport (>1000 ft). The low temperatures and high flow rates for the large volume springs imply relatively shallow transport paths and short aquifer 
residence times. It is likely that less permeable layers located below the volcanic peaks may be important in terms of focusing groundwater flow toward a localized discharge area. For example, hydrothermally altered lavas and pyroclastic deposits can contain secondary minerals (e.g. clays and silicification) that greatly reduce the permeability of the altered layers. Altered rocks are expected to occur at depth beneath all three volcanoes. In addition, outside of the volcanic highlands, both the Hat Creek and the Giant Crater lava flows are underlain by older Plio-Pleistocene basalts and diatomaceous lake-bed deposits (Macdonald, 1966). The lake-bed deposits in particular may provide a barrier to the downward percolation of groundwater, enhancing lateral transport in the overlying basaltic layers.

\section{CONCLUSIONS}

The Lassen-Hat Creek and the Medicine Lake-Fall River Springs groundwater systems share a number of common characteristics. Key similarities include:

- Laterally extensive, high permeability Quaternary basalt flows that extend from the base of the volcanoes, providing major conduits for groundwater transport away from high precipitation areas on the volcanoes.

- Large volume springs occurring at the terminus of these basalt flows.

- $\delta^{18} \mathrm{O}$ values for the large volume springs that indicate groundwater recharge at high elevations on the volcanic edifice.

- Radiocarbon and $\delta^{13} \mathrm{C}$ values for the large volume springs that indicate large quantities of dissolved magmatic $\mathrm{CO}_{2}$ derived from shallow, active geothermal systems underlying these volcanoes.

The groundwater system at Mt. Shasta contrasts the Lassen and Medicine Lake systems in several ways. Large volume spring flows at Mt. Shasta emerge mostly from deep erosional incisions in the canyons of the McCloud and Upper Sacramento Rivers. The 
$\delta^{18} \mathrm{O}$ values of the largest spring flows indicate that the majority of recharge did not occur at high elevations on Mt. Shasta, but rather at lower elevations along its flanks. Magmatic $\mathrm{CO}_{2}$ emerging from Mt. Shasta occurs predominantly at low elevations on the south and southwestern side of the volcano. Because Shasta lacks a shallow geothermal system such as that at Lassen and Medicine Lake, magmatic $\mathrm{CO}_{2}$ is largely absent in high elevation recharge, and is only seen in waters that discharge at low elevations along the flank of the volcano.

Isotopic evidence presented in this report indicates that groundwater emerging from Fall River Springs contains large amounts of magmatic $\mathrm{CO}_{2}$ gas derived from Medicine Lake volcano. Although this does not in itself indicate a direct physical connection between the geothermal system and the Fall River Springs recharge system, it does clearly imply that the Fall River Springs recharge system directly overlies the geothermal system, and that $\mathrm{CO}_{2}$ gas leaks upward from the geothermal system. Moreover, the large quantity of magmatic $\mathrm{CO}_{2}$ in the Fall River Springs system is a strong indicator that the area of geographical overlap between the cold spring recharge zone and the underlying geothermal reservoir is quite large.

Studies aimed at determining the potential environmental impact of geothermal energy development in the Medicine Lake highlands must consider these facts. The connectivity between the spring water recharge system and the underlying geothermal reservoir needs to be considered before and during geothermal energy development. Of possible concern is a scenario whereby the removal of heat and water from the geothermal system may enhance vertical transport of the fresh groundwater and cause a head reduction at the Fall River Springs discharge point. Alternatively, if the buoyancy of the geothermal water is great enough, its utilization may cause it to migrate into the fresh groundwater, possibly resulting in temperature and salinity increases in the Fall River Springs. The evidence in this report cannot support or refute either of these scenarios or any other possible occurrences. The evidence does however show that much of the Fall River Springs is recharged on the 
Medicine Lake Volcano and that recharge has interacted with magmatic $\mathrm{CO}_{2}$ whose source must be the large geothermal system. 


\section{REFERENCES}

Bowers, D., 1997, personal communication, Pacific, Gas, and Electric Company.

Christiansen, R.L., 1982, Volcanic hazard potential in the California Cascades. Calif. Div. Mines Geol. Special Pub. 63: 41-59.

Clynne, M.A., 1990, Stratigraphic, lithologic, and major element geochemical constraints of magmatic evolution of the Lassen Volcanic Center, California, Jour. Geophys. Res., 95: 19651-19669.

Coleman, M.L., Sheperd, T.J., Durham, J.J., Rouse, J.E., and Moore, G.R., 1982. Reduction of water with zinc for hydrogen isotope analysis. Anal. Chem., 54: 993-995.

Craig, H., 1961a, Standard for reporting concentrations of deuterium and oxygen-18 in natural waters. Science, 133: 1833-1834.

Craig, H., 1961b, Isotopic variations in meteoric waters. Science, 133: pp. 1702-1703.

Dansgaard, W., 1964, Stable isotopes in precipitation. Tellus, 16: 436-468.

Davisson, M.L. and Velsko, C.A., 1994, Vacuum technique for stripping of $\mathrm{CO}_{2}$ from natural waters for ${ }^{14} \mathrm{C}$ determination by accelerator mass spectrometry. Lawrence Livermore National Lab Report UCRL-JC-119176, 18 p.

Donnelly-Nolan, J.M., Champion, D.E., Grove, T.L., Baker, M.B., Taggert, J.E., and Bruggman, P.E., 1991, The Giant Crater lava field: geology and geochemistry of a compositionally zoned, high-alumina basalt to basaltic andesite eruption at Medicine Lake volcano, California. Jour. Geophys. Res., 96: 21843-21863.

Ellis, M.J., 1997, Shasta crayfish: A threatened California native. Outdoor California, 58 (2): 4-6.

Epstein, S. and Mayeda T., 1953, Variation of $18 \mathrm{O}$ content of waters from natural sources. Geochim. Cosmochim. Acta 4: 213-224.

Evans, J.R., 1963, Geology of some lava tubes, Shasta County. Calif. Div. Mines Geol. Mineral Information Service, 16 (3): 1-7.

Evans, J.R. and Zucca, J.J., 1988, Active high-resolution seismic tomography of compressional wave velocity and attenuation structure at Medicine Lake volcano, northern California Cascade Range. Jour. Geophys. Res., 93: 15016-15036. 
Fontes, J.Ch., 1992, Chemical and isotopic constraints on the ${ }^{14} \mathrm{C}$ dating of groundwater. in Taylor, R.E., Long, A., Kra, R.S. (eds), Radiocarbon After Four Decades, pp. 242261.

Ingraham, N.L. and Taylor, B.E., 1991, Light stable isotope systematics of large-scale hydrologic regimes in California and Nevada. Water Resour. Res. 27: 77-90.

Macdonald, G.A., 1966, Geology of the Cascade Range and Modoc Plateau. In: Bailey, E.H. (ed.), Geology of Northern California, Calif. Div. Mines Geol. Bull. 190, pp. 65-96.

Manga, M., 1997, A model for discharge in spring-dominated streams and implications for the transmissivity and recharge of quaternary volcanics in the Oregon Cascades. Water Resour. Res., 33: 1813-1822

McNichol, A.P., Jones, G.A., Hutton, D.L., Gagnon, A.R., and others, 1994, The rapid preparation of seawater sigma- $\mathrm{CO}_{2}$ for radiocarbon analysis at the National Ocean Sciences AMS Facility. Radiocarbon, 36, 237-246.

Meinzer, O.E., 1927, Large springs in the United States. U.S. Geol. Survey WaterSupply Paper 557, 94 p.

Muffler, L.J.P., Nehring, N.L., Truesdell, A.H., Janik, C.J., Clynne, M.A. and Thompson, J.M., 1982, The Lassen geothermal system. U.S. Geol. Survey Open-File Report 82-926, 8 p.

Muffler, L.J.P., Clynne M.A., Champion, D.E., 1994, Late Quaternary normal faulting of the Hat Creek Basalt, northern California. Geol. Soc. Amer. Bull., 106: 195-200.

Rantz, S.E., 1969, Mean annual precipitation in the California region. U.S. Geol. Surv. Basic Data Compilation, Isohyetal Map, scale 1:1,000,000.

Rose, T.P. and Davisson, M.L., 1996, Radiocarbon in hydrologic systems containing dissolved magmatic carbon dioxide. Science, 273: 1367-1370.

Rose, T.P., Davisson, M.L., and Criss, R.E., 1996, Isotope hydrology of voluminous cold springs in fractured rock from an active volcanic region, northeastern California. Jour. Hydrol., 179: 207-236.

Smith, G.I., Friedman, I., Klieforth, H.E., and Hardcastle, K., 1979, Aerial distribution of deuterium in eastern California precipitation, 1968-1969. Jour. Appl. Meteor., 18: 172-188. 


\section{FIGURE CAPTIONS}

Figure 1: Regional map of northern California volcanic centers showing Quaternary age lava flows (hatched areas). The Giant Crater lava field and the Hat Creek basalt both extend from the base of volcanic peaks and terminate near the Pit River where large volume springs emerge. Volcanic flows associated with Mt. Shasta are fragmentary, and large volume springs instead emerge in areas of deep erosion.

Figure 2: Mean annual discharge for Rising River and Crystal Lake springs for the years 1987-1992, corresponding to a period of drought in California. The data are normalized to the 1987 discharge at each spring to show the percent decrease in flow as the drought progresses. Discharge rates were determined from the difference in flow along Hat Creek measured at gauging stations located upstream and downstream of the springs. The data show that the springs respond rapidly to decreases in precipitation rate in the recharge area.

Figure 3: Isohyetal map shows that precipitation in inches per year is regionally high in the three volcanic edifices, but much lower in the areas where large volume springs emerge.

Figure 4a: Moderate to large volume springs emerge throughout the Lassen-Hat Creek Valley area, but the most significant flows are Rising River, Crystal Lake, Burney Falls, and Big Spring. Lassen peak also host thermal springs that are surface expressions of an large and shallow geothermal system below its summit.

Figure 4b: The distinctive variation in $\delta^{18} \mathrm{O}$ values of the large volume springs in the Lassen-Hat Creek Valley area indicate that recharge occurs at different geographic locations and elevations. Figure is from Rose et. al. (1996).

Figure 4c: Small volume spring flows whose recharge areas are near their sampling locations show an expected west to east decrease in $\delta^{18} \mathrm{O}$ that is accentuated by steep elevation gains on Lassen Peak. Since Lassen Peak and the highlands to the east have a high annual precipitation rate and low $\delta^{18} \mathrm{O}$ values, recharge to Rising River and Crystal Lake must be derived from this area.

Figure 4d: A large and active geothermal system below Lassen Peak discharges $\sim 10^{7} \mathrm{~kg} / \mathrm{yr}$ of magmatic $\mathrm{CO}_{2}$, which at least $20 \%$ dissolves in groundwater as dissolved inorganic carbon. The magmatic $\mathrm{CO}_{2}$ is radiocarbon-absent and its mixture in regional groundwater 
delineates a distinct flow path from the Lassen area to the Rising River. Figure is from Rose and Davisson (1996).

Figure 5: The comparison of $\delta^{13} \mathrm{C}$ and radiocarbon $\left({ }^{14} \mathrm{C}\right)$ of dissolved inorganic carbon (DIC) in the Lassen-Hat Creek Valley waters distinguish four different carbon endmembers all influencing regional groundwater. These include 1) a biogenic DIC from plant respiration dissolved in recharging groundwater, 2) a DIC isotopically equilibrated with the atmosphere usually observed in evaporated surface water or high elevation runoff, 3) a mixture of magmatic DIC and DIC equilibrated with atmospheric $\mathrm{CO}_{2}$ that occurs as recharge beneath Lassen Peak, and 4) DIC from hot springs dissolved in regional groundwater.

Figure 6a: Large volume spring flows around Mt. Shasta are limited to Big Spring and Shasta Springs. Both occur in deep erosional incisions into volcanic flow deposits. Cold temperature soda springs are observed in low elevation areas on the south and southwestern sides of Mt. Shasta.

Figure 6b: The $\delta^{18} \mathrm{O}$ value of Ash Creek represents high elevation snow melt compositions. Only Sisson Spring has the same value, while the large volume springs have much higher values that indicate recharge is predominantly at lower elevations.

Figure 6c: Significant levels of magmatic $\mathrm{CO}_{2}$ dissolved in spring waters around Mt. Shasta are limited to areas on the south and southwest side. In particular, half the dissolved carbon in Sisson Spring is magmatically derived. The radiocarbon content of Ash Creek indicates that no magmatic $\mathrm{CO}_{2}$ emerges from high elevations on the east side and is consistent with the general lack of a large geothermal system below the summit of Shasta.

Figure 7: The comparison of $\delta^{13} \mathrm{C}$ and ${ }^{14} \mathrm{C}$ in groundwater of the Shasta area indicates that only biogenic DIC, atmospherically equilibrated DIC, and magmatic $\mathrm{CO}_{2}$ are the endmembers influencing regional groundwater. The lack of a magmatic DIC end-member as seen in the case of Lassen (see Fig. 5) indicates that magmatic $\mathrm{CO}_{2}$ dissolution into Shasta groundwater occurs in a closed system. The Fall River isotopic values fall in a field that suggest that in the Medicine Lake area, magmatic $\mathrm{CO}_{2}$ dissolution likely occurs in a partially open system similar to Lassen. 
Figure 8a: The $\delta^{18} \mathrm{O}$ value for Fall River springs is consistent with the $\delta^{18} \mathrm{O}$ values observed in the Medicine Lake Highlands area and differ from that of the Mt. Shasta region. The annual discharge from Fall River Springs require an $\sim 750 \mathrm{mi}^{2}$ recharge area with 25 inches of annual recharge. Medicine Lake Volcano likely comprises half this recharge with the remainder probably occurring along the surface of Giant Crater lava field. The lack of surface drainage in these areas suggest that almost all the annual precipitation is recharge into the groundwater.

Figure 8b: Radiocarbon in two local spring flows on Medicine Lake Volcano have atmospheric contents. Radiocarbon in Fall River Springs has been diluted with magmatic $\mathrm{CO}_{2}$ at a minimum of $27 \%$. This requires a magmatic $\mathrm{CO}_{2}$ flux on the order of $2.5 \times 10^{7}$ $\mathrm{kg} / \mathrm{yr}$ as DIC, which can only be derived from a large active geothermal system such as found beneath Medicine Lake Volcano.

Figure 9a: Idealized cross-section of a stratocone volcano illustrates conceptually groundwater recharge and flow in the Mt. Shasta region. Recharge of annual snow melt is limited by vertical permeability of the layered volcanic deposits. In Mt. Shasta, recharge is likely limited to shallow permeable layers at lower elevations. Likewise, the layered volcanics and lack of a large geothermal system at Shasta limited magmatic $\mathrm{CO}_{2}$ discharge to low elevations areas. Most dissolution of magmatic $\mathrm{CO}_{2}$ in regional groundwater is limited to these low elevation areas.

Figure 9b: Conceptualization of groundwater flow in the Lassen-Hat Creek Valley and the Medicine Lake-Fall River Springs systems. Fractures created by volcanic domes, or possible ring fractures in the case of Medicine Lake, enhance vertical recharge of annual snow melt. The very high permeability of the Hat Creek basalt flow and the Giant Crater lava field provide conduits for rapid groundwater transport over long lateral distances to lower elevations. In the case of Medicine Lake, the permeability of the lava field must be high enough that all recharge remains beneath the ground. 


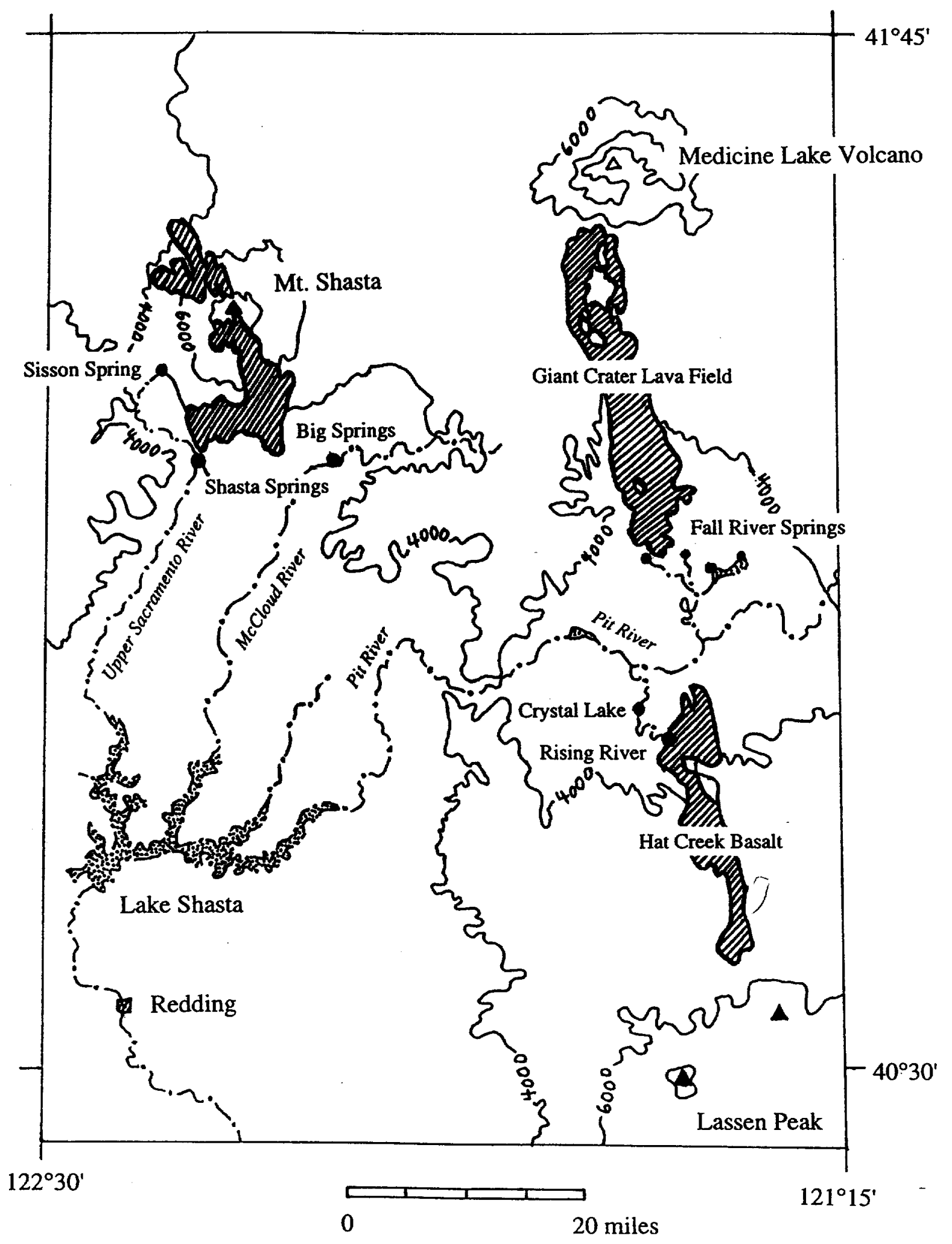

Figure 1 


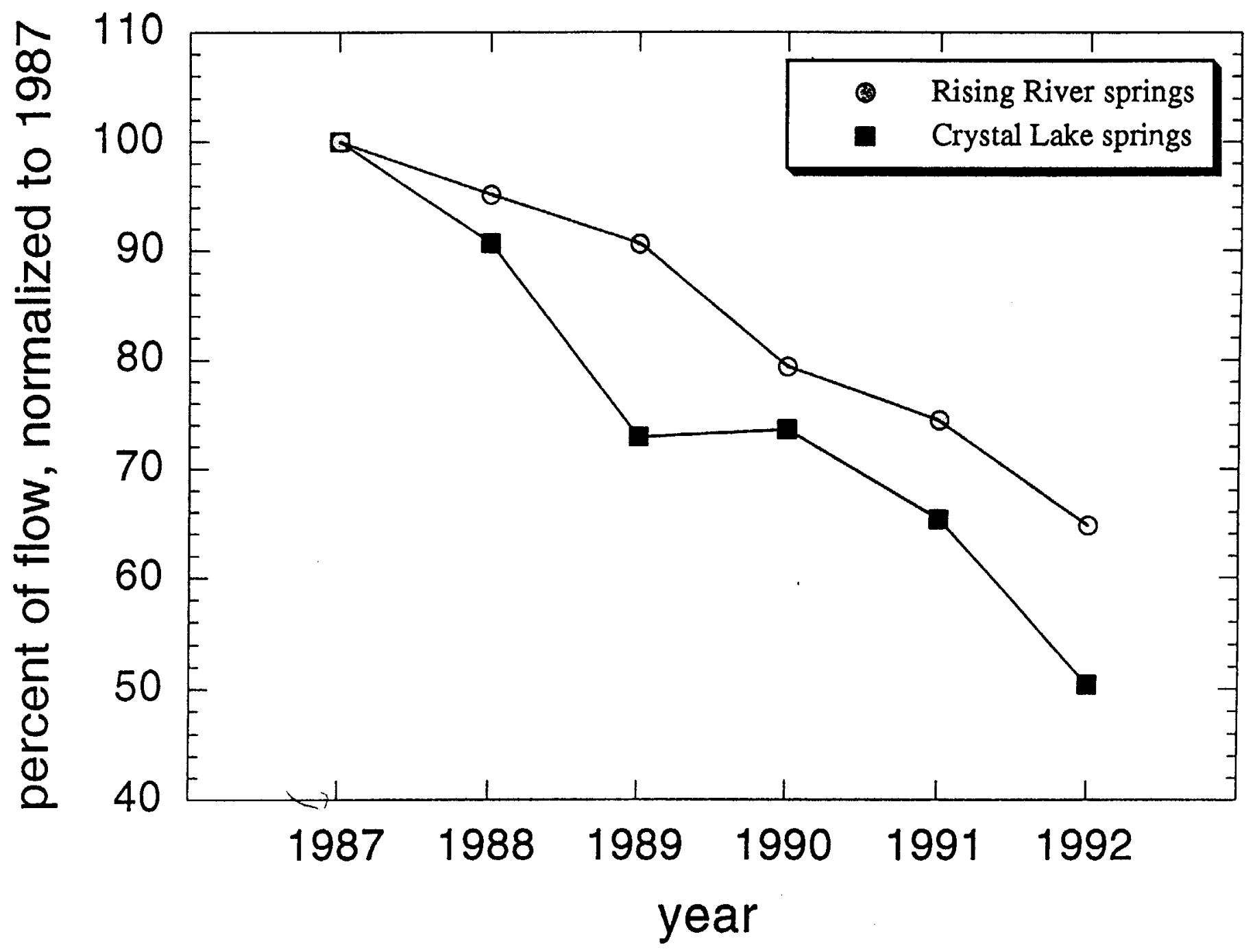

Figure 2 

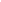


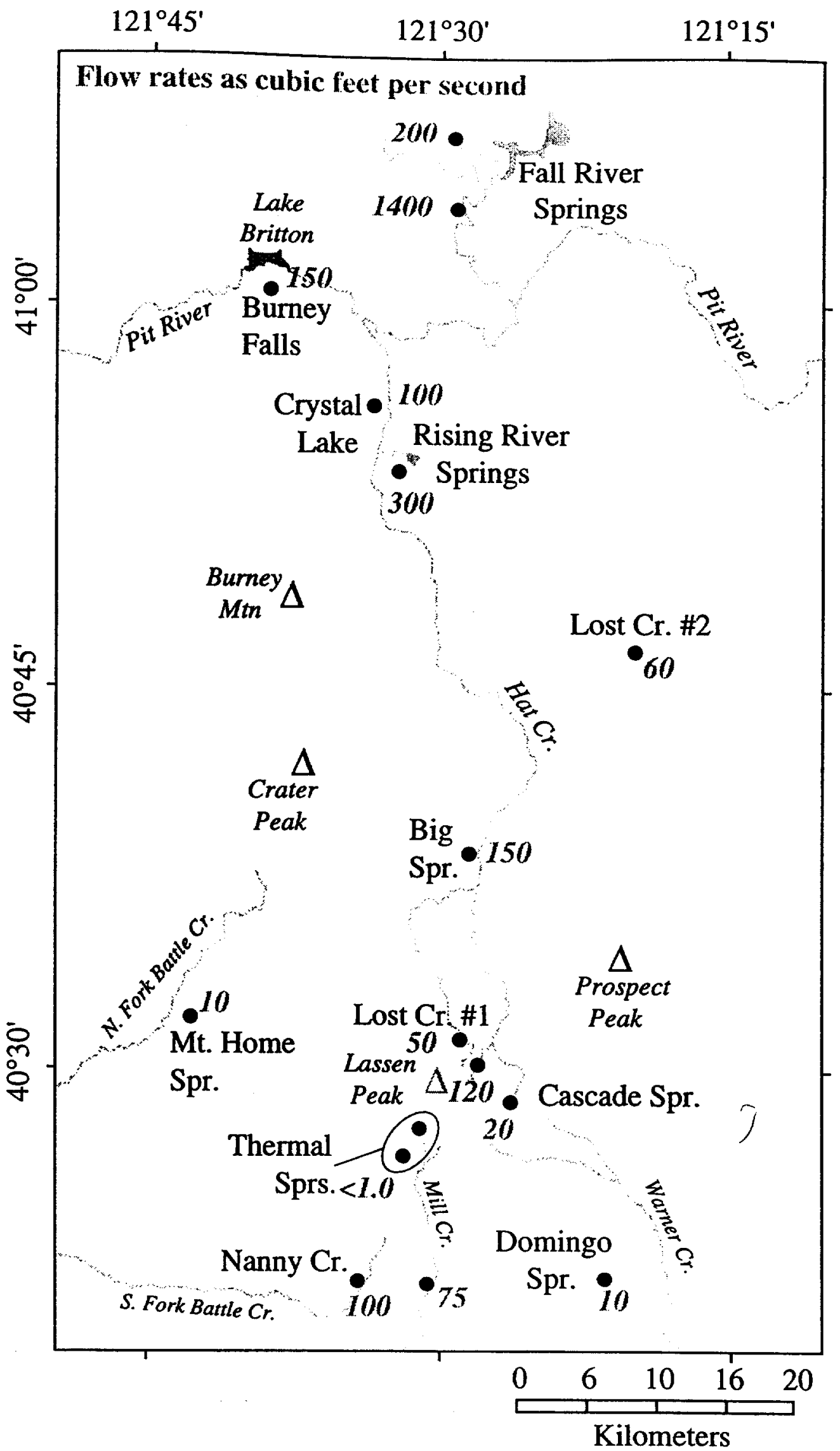

Figure 4a 


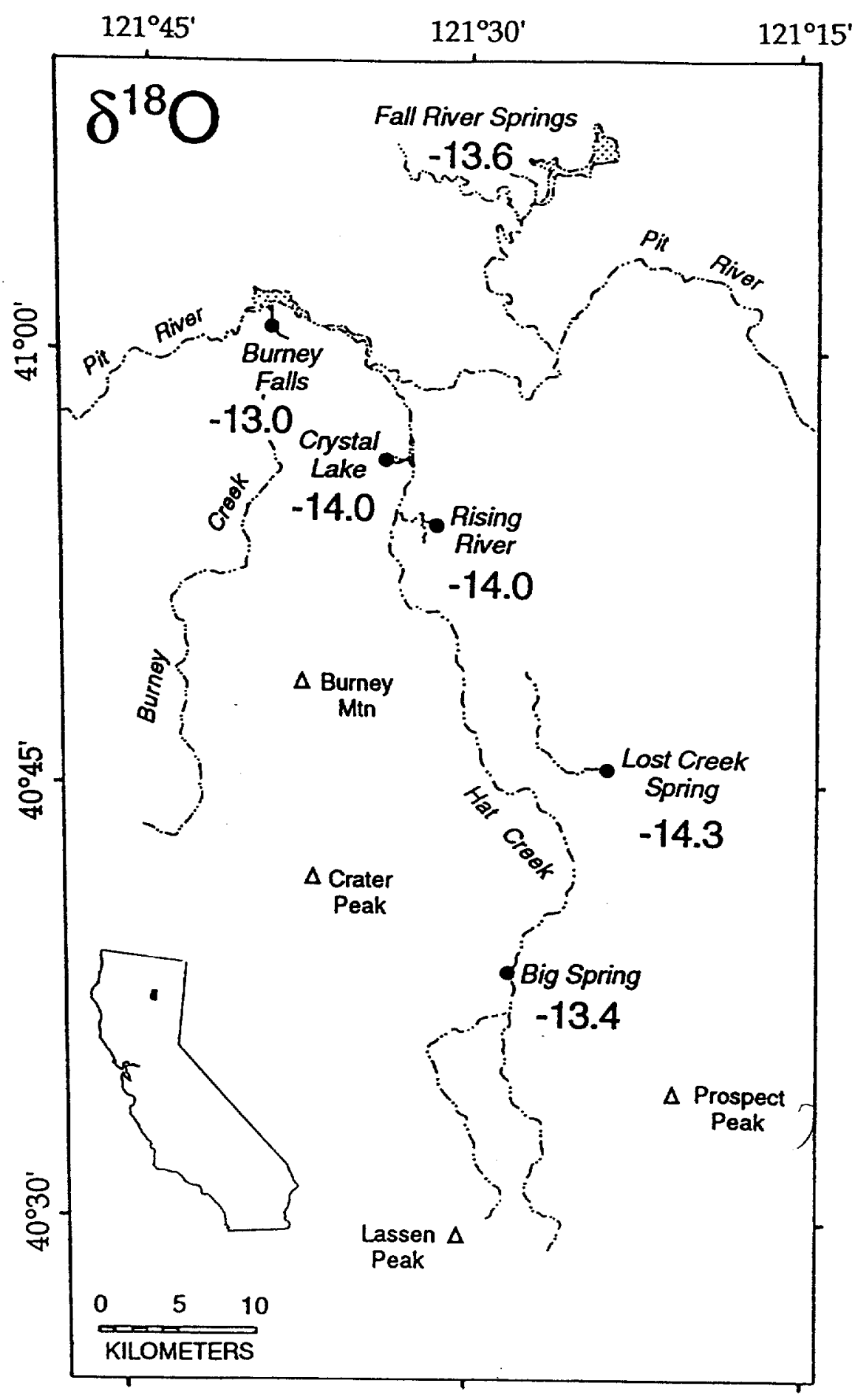

Figure 4b 


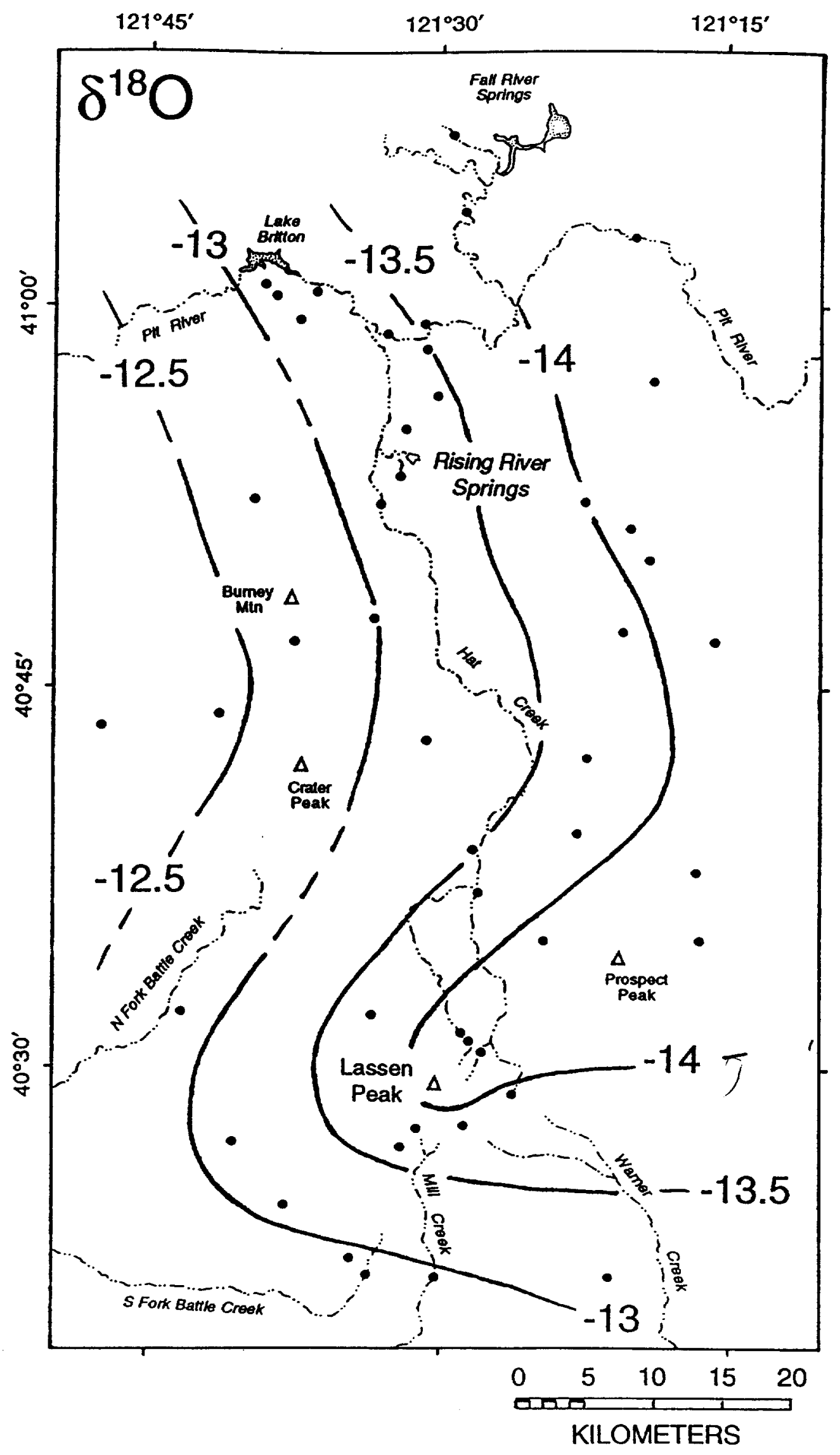

Figure 4c 


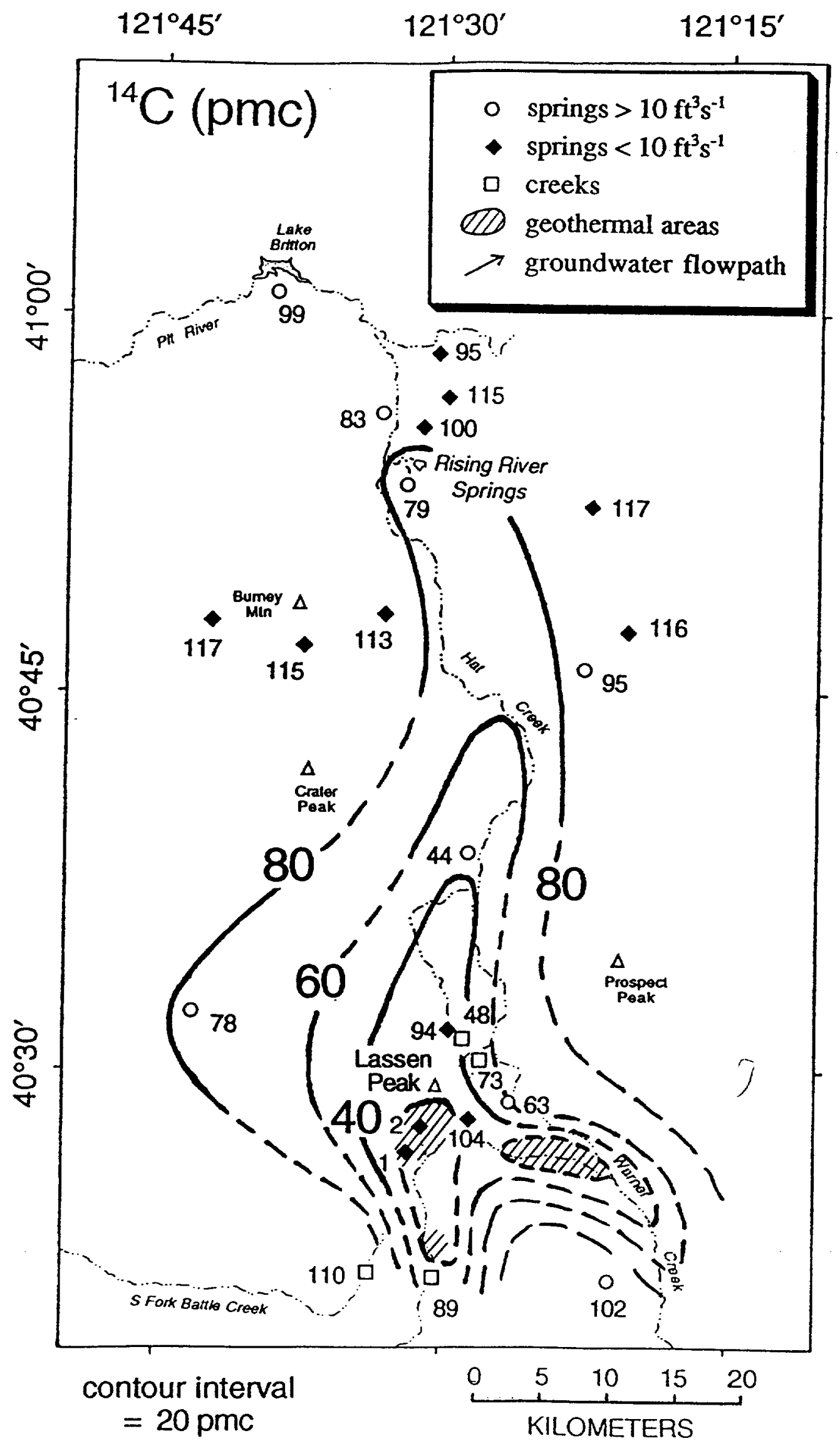

Figure 4d 


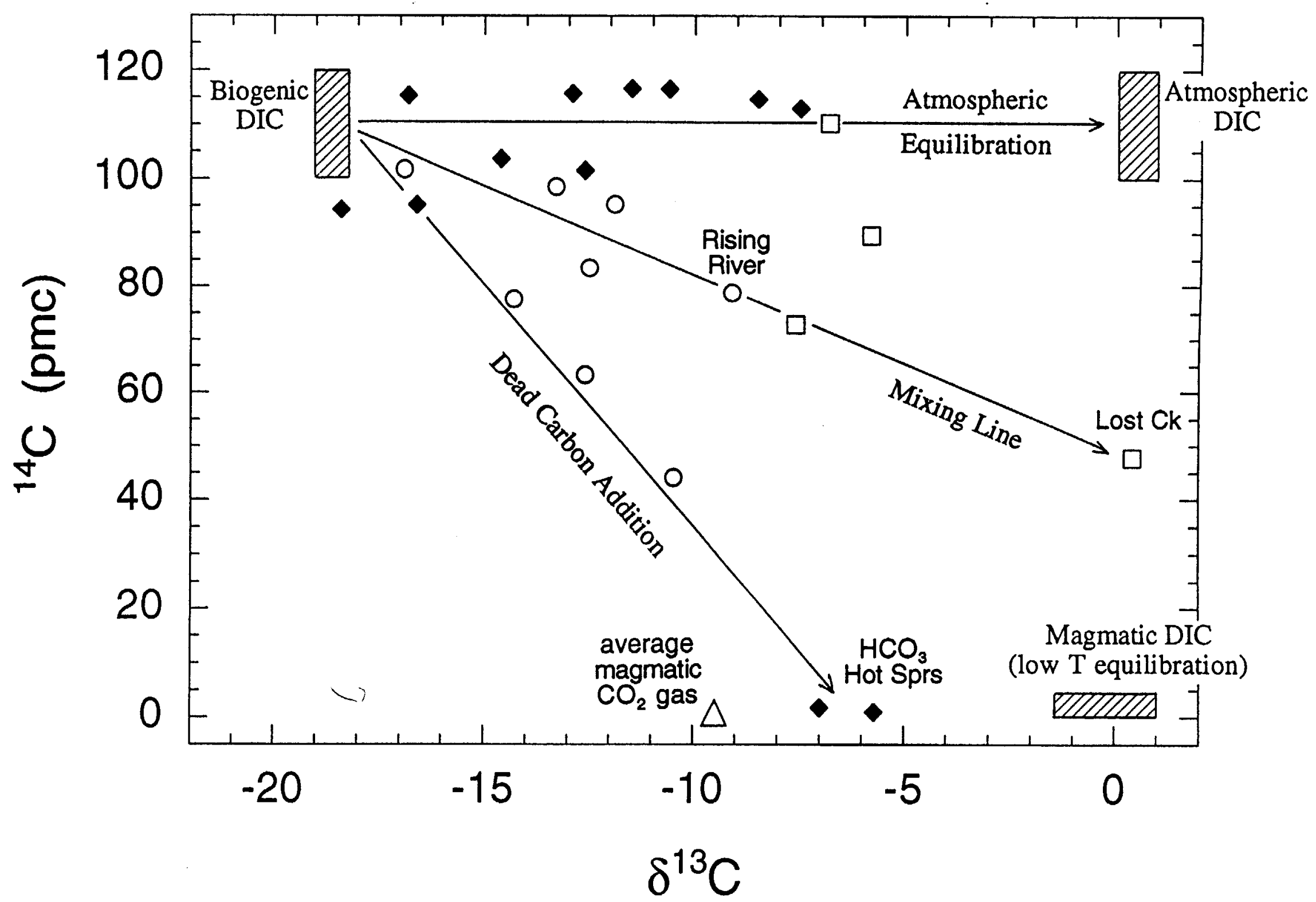




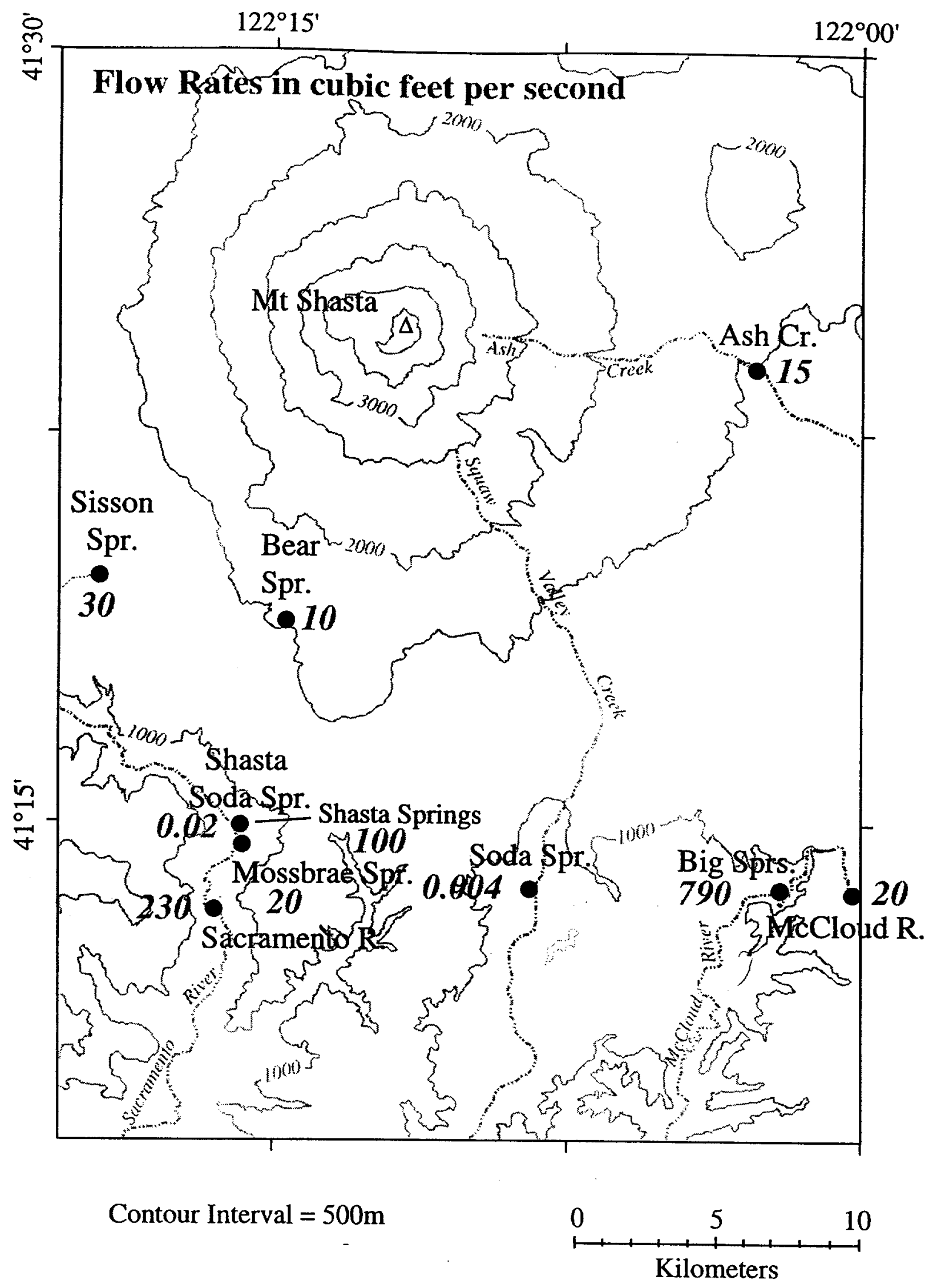

Figure 6a 


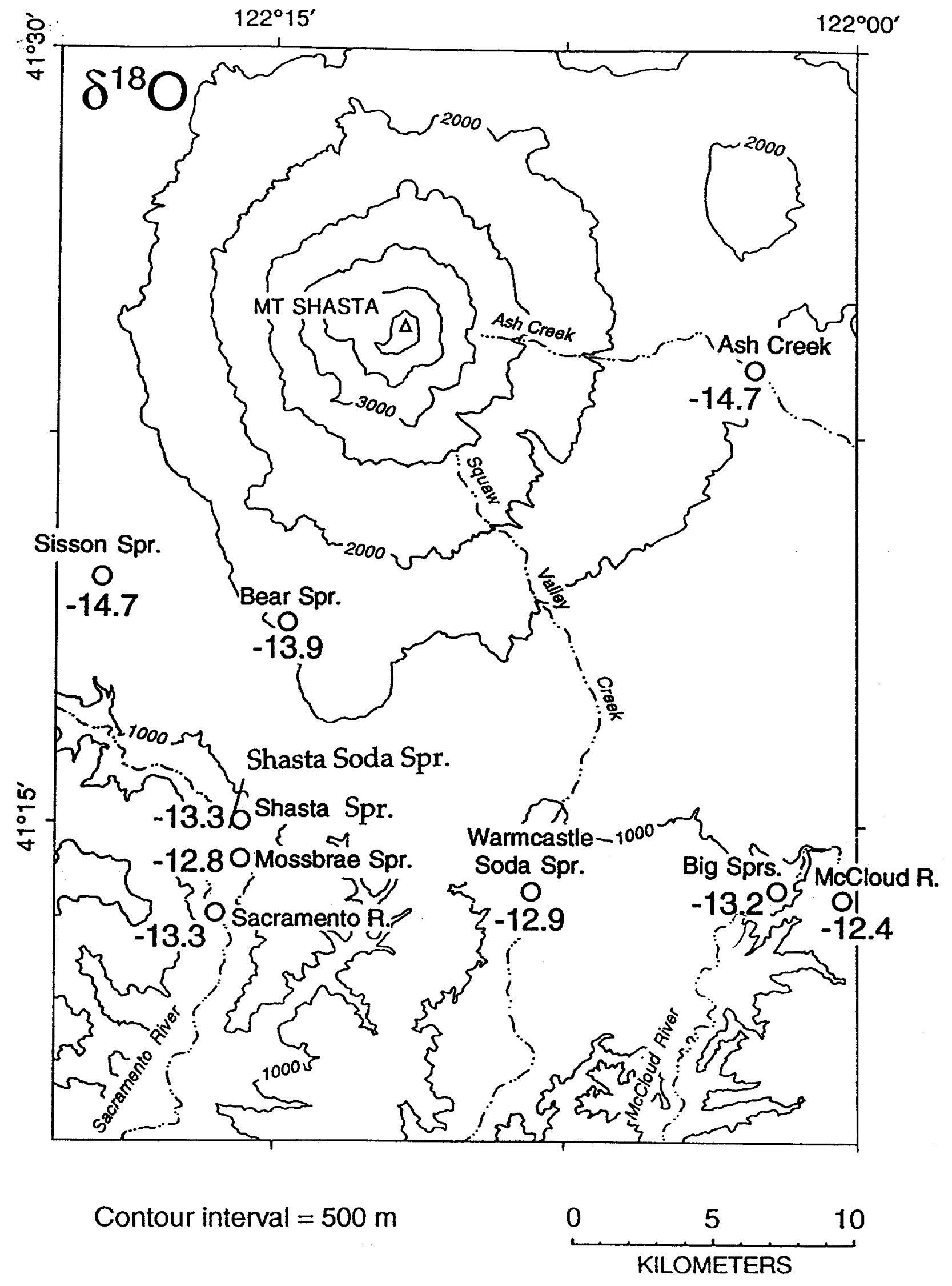

Figure 6b 


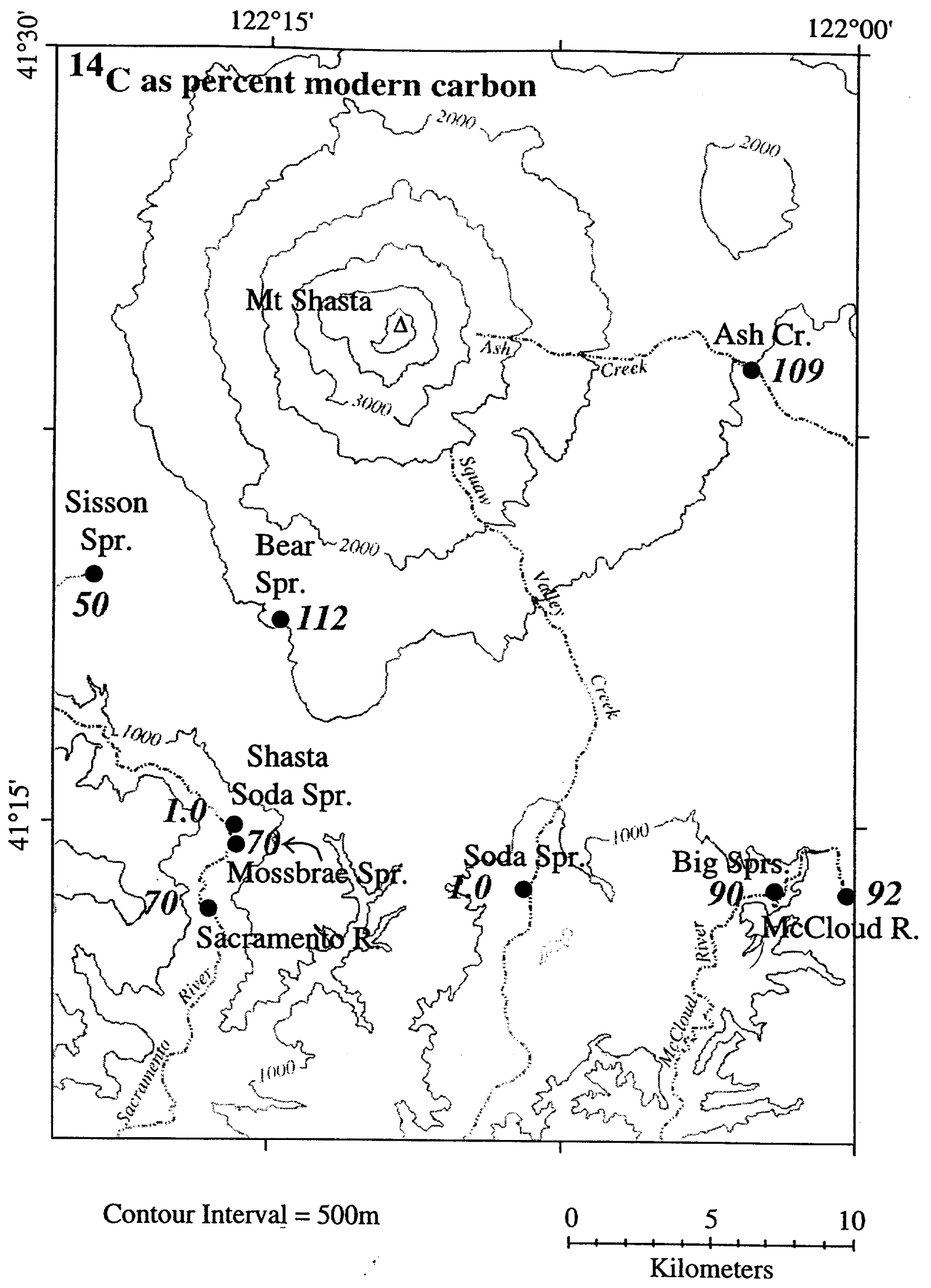

Figure $6 c$ 


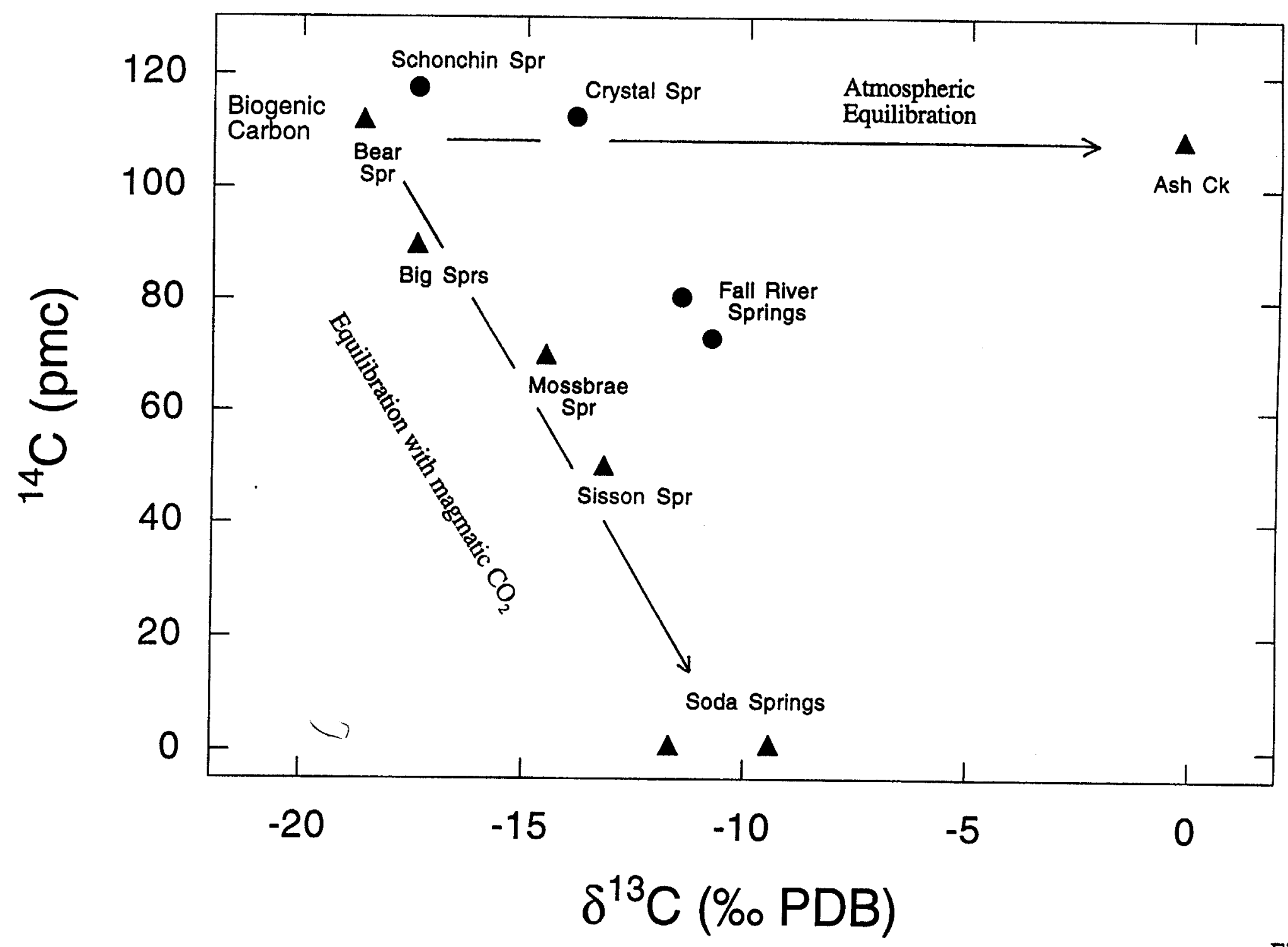

Figure 7 


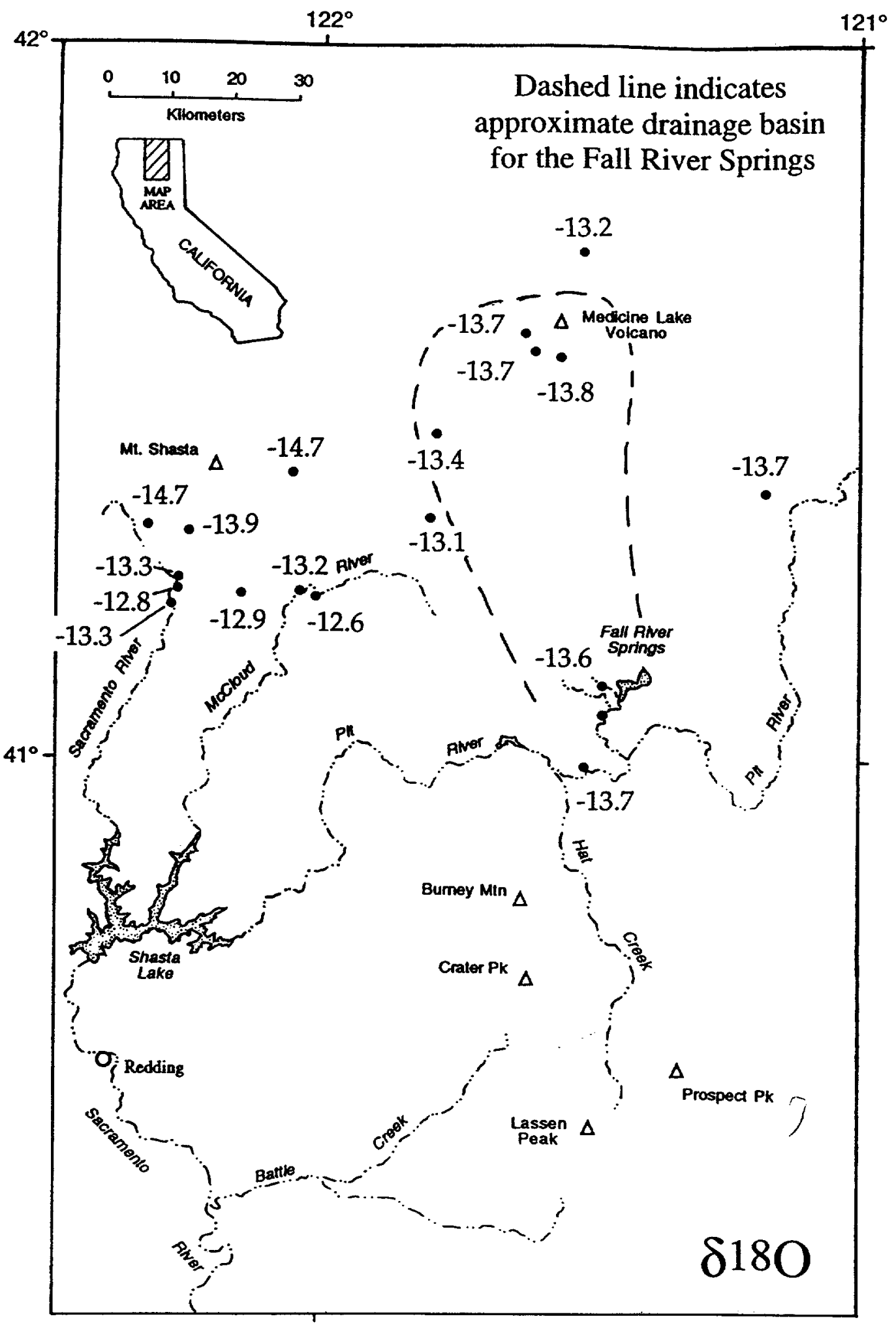

Figure $8 \mathrm{a}$ 


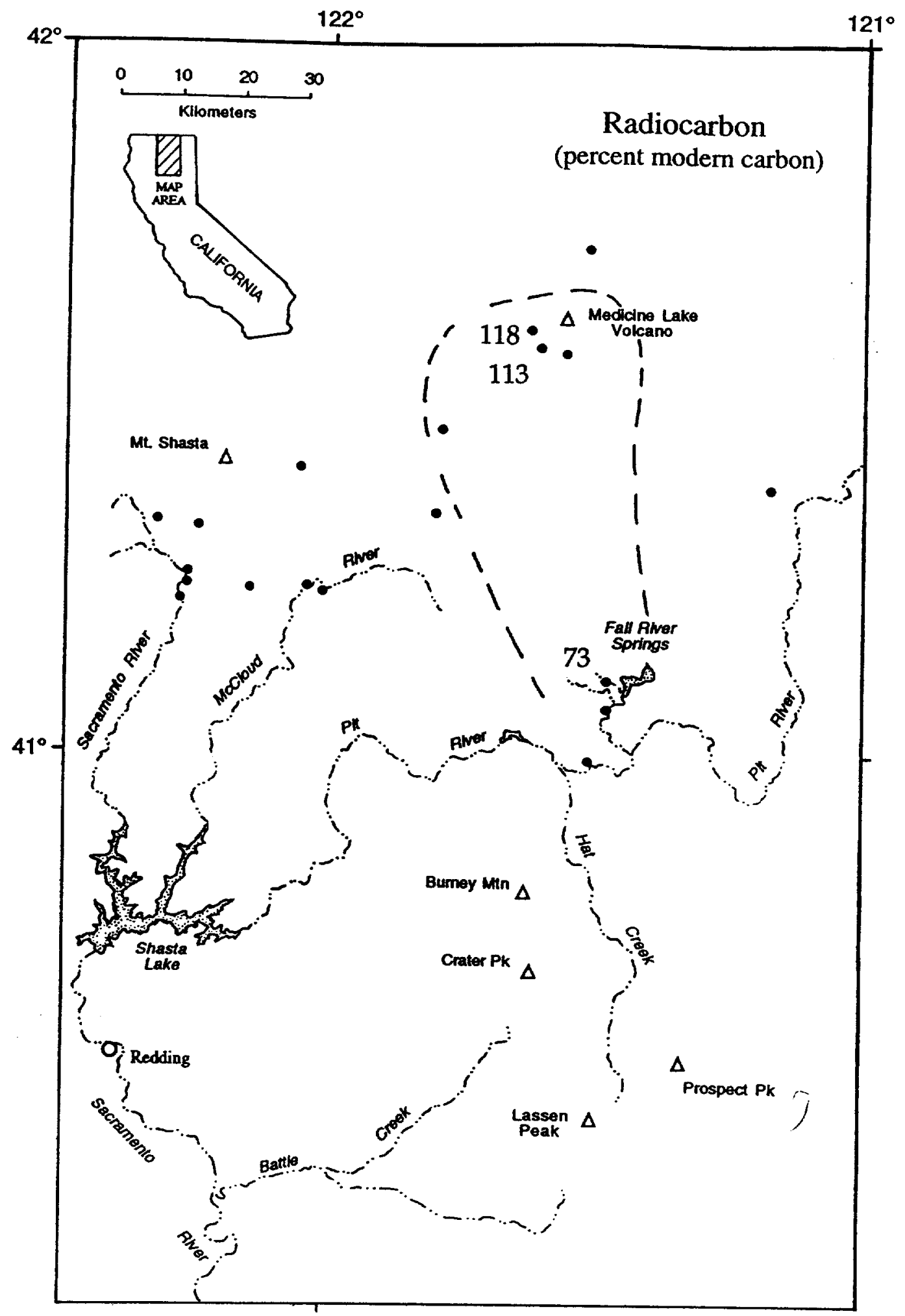

Figure 8b 


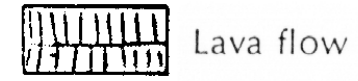

$\because \because 9$ Pyroclastic layer

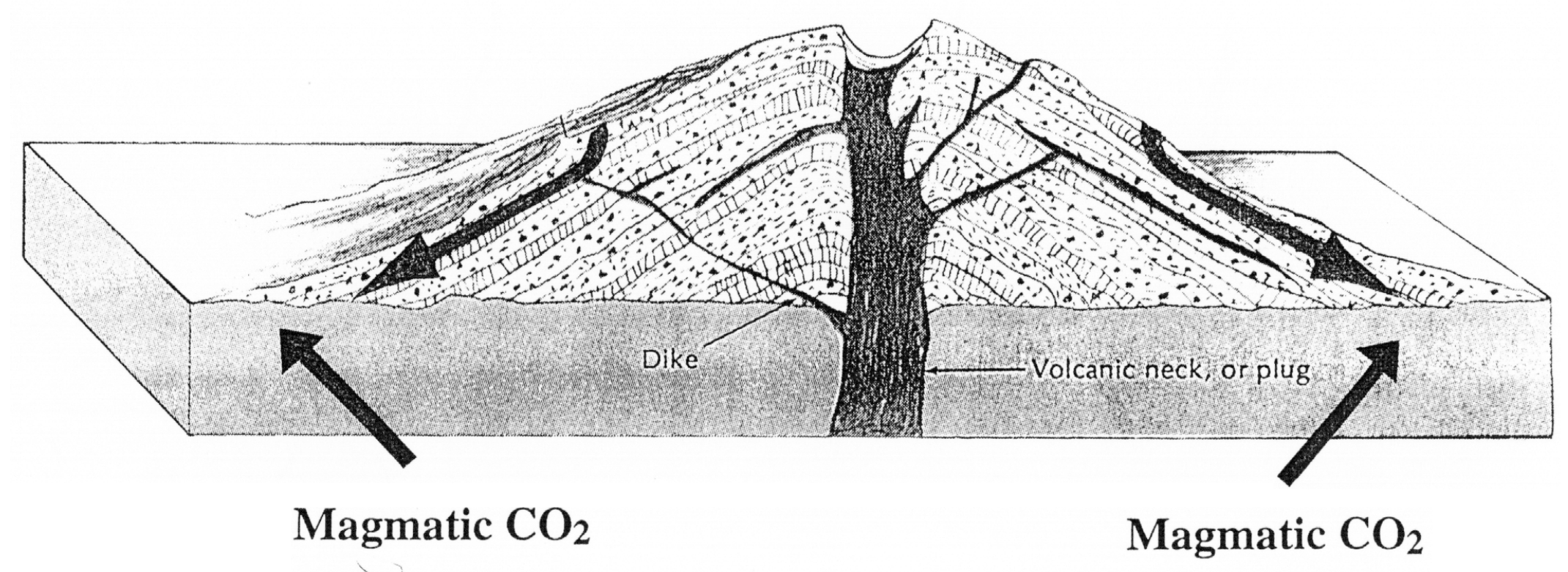




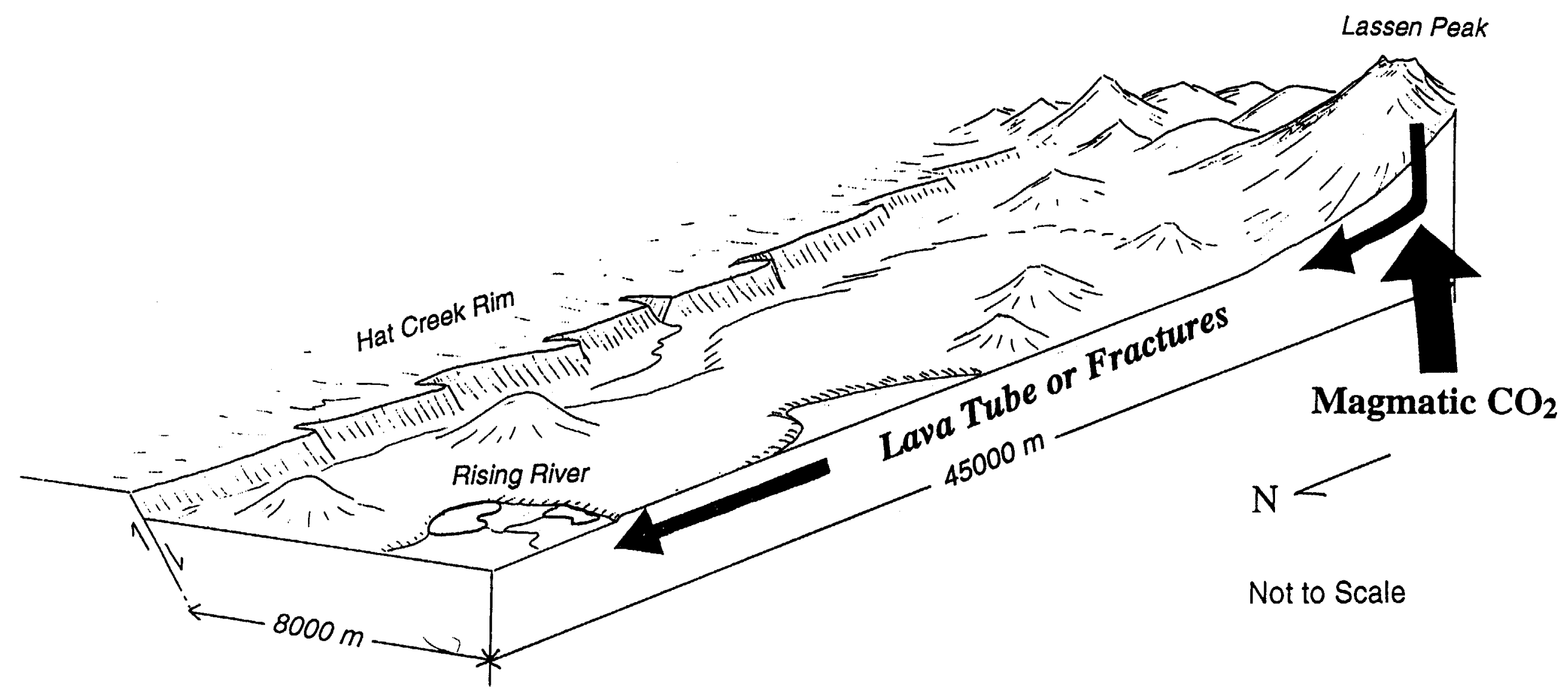


Table 1. Chemical and Isotopic Data

\begin{tabular}{|c|c|c|c|c|c|c|c|c|c|c|}
\hline Sample Location & Date & $\delta^{18} \mathrm{O}$ & $\delta \mathrm{D}$ & $\delta^{13} \mathrm{C}$ & $\begin{array}{l}{ }^{14} \mathrm{C} \\
(\mathrm{pmc})\end{array}$ & $\begin{array}{c}\text { DIC } \\
\left(\mathrm{ppm} \mathrm{HCO}_{3}\right)\end{array}$ & $\begin{array}{c}\text { alkalinity } \\
\left(\mathrm{ppm} \mathrm{CaCO}_{3}\right)\end{array}$ & $\begin{array}{c}\text { conductivity } \\
(\mu \mathrm{S} / \mathrm{cm})\end{array}$ & $\mathrm{pH}$ & $\mathrm{T}\left({ }^{\circ} \mathrm{C}\right)$ \\
\hline \multicolumn{11}{|l|}{ Lassen Region } \\
\hline Bicarbonate Hot Spring \#1 & $09 / 95$ & -11.6 & -87 & -5.7 & 1.0 & 325 & 250 & 2000 & 6.5 & 80 \\
\hline Bicarbonate Hot Spring \#2 & $09 / 95$ & -12.8 & -93 & -7.0 & 1.8 & 690 & 300 & 1600 & 6.3 & 60 \\
\hline Baker Spring & $06 / 95$ & -13.6 & - & - & - & - & 100 & 223 & 7.0 & 9 \\
\hline Bidwell Spring & $06 / 95$ & -14.2 & -105 & - & - & - & 30 & 67 & 7.3 & 6 \\
\hline Big Spring $-1 *$ & $08 / 94$ & -13.4 & - & -11.0 & 41.1 & 88 & 70 & 141 & 7.0 & 8 \\
\hline Big Spring - 2 & $02 / 95$ & -13.4 & -97 & {$[-7.6]$} & 47.2 & 68 & 70 & 141 & 7.1 & 7 \\
\hline Big Spring - 3 & $06 / 95$ & -13.5 & - & -10.1 & - & 83 & 70 & 139 & 6.7 & 7 \\
\hline Bowers Well (Cassel) * & $02 / 94$ & -13.8 & -98 & -16.0 & 94.1 & 100 & - & 117 & 6.9 & 11 \\
\hline Box Canyon Spring & $06 / 95$ & -14.2 & - & - & - & - & 30 & 73 & 6.9 & 6 \\
\hline Burney Creek & $02 / 95$ & -11.9 & - & - & 109.1 & 18 & 30 & 60 & 7.0 & 3 \\
\hline Burney Falls - $1 *$ & $05 / 94$ & -13.0 & - & -13.3 & 98.6 & 60 & - & 78 & - & 11 \\
\hline Burney Falls - 2 & $02 / 95$ & -13.1 & -90 & {$[-11.5]$} & 99.7 & 53 & 70 & 122 & 6.9 & 7 \\
\hline Burney Falls - 3 & $06 / 95$ & -13.0 & - & - & - & - & 65 & 123 & 8.1 & 9 \\
\hline Burney Muni. Well \#6 * & $02 / 94$ & -12.7 & -90 & -18.8 & 88.3 & 50 & - & 68 & 7.8 & 12 \\
\hline Burney Spring * & $05 / 94$ & -12.7 & -89 & -16.8 & 115.4 & 36 & - & 40 & - & 8 \\
\hline Cascade Springs & $09 / 95$ & -13.7 & -96 & -12.5 & 63.3 & 32 & 26 & 53 & 8.2 & 5 \\
\hline Cassel Muni. Well \#1 * & $02 / 94$ & -13.6 & -99 & -15.9 & 90.9 & 142 & - & 182 & 7.2 & 10 \\
\hline Cinder Flats Spring * & $05 / 94$ & -10.4 & -86 & -8.5 & 114.7 & 138 & - & 190 & - & 18 \\
\hline Clover Mtn Spring * & $05 / 94$ & -12.4 & - & - & - & - & - & - & - & - \\
\hline Coble Spring & $06 / 95$ & -14.3 & - & - & - & - & 120 & 199 & 7.1 & 17 \\
\hline Compton Spring & $06 / 95$ & -13.3 & - & - & - & - & 90 & 157 & 6.7 & 15 \\
\hline Cornaz Spring * & $05 / 94$ & -10.2 & -84 & -7.5 & 113.0 & 95 & - & 138 & - & 16 \\
\hline Coyote Spring & $06 / 95$ & -13.6 & - & - & - & - & 80 & 147 & 7.6 & 11 \\
\hline Crystal Lake Spr $-1 *$ & $02 / 94$ & -14.0 & -102 & -13.1 & 83.0 & 56 & - & 98 & 8.2 & 10 \\
\hline Crystal Lake Spr $-2 *$ & $05 / 94$ & -13.9 & - & -11.9 & 84.0 & 56 & - & 103 & 8.5 & 14 \\
\hline Digger Creek & 09/95 & -13.1 & - & -13.4 & - & 45 & 35 & 70 & 5.8 & 8 \\
\hline Domingo Spring & $09 / 95$ & -13.2 & -96 & -16.8 & 101.8 & 67 & 52 & 126 & 8.3 & 9 \\
\hline Doyle Ranch Well * & $10 / 93$ & -12.4 & -92 & -17.3 & 109.9 & 250 & - & 314 & - & - \\
\hline
\end{tabular}


Table 1. Chemical and Isotopic Data

\begin{tabular}{|c|c|c|c|c|c|c|c|c|c|c|}
\hline Sample Location & Date & $\delta^{18} \mathrm{O}$ & $\delta \mathrm{D}$ & $\delta^{13} \mathrm{C}$ & $\begin{array}{l}{ }^{14} \mathrm{C} \\
(\mathrm{pmc})\end{array}$ & $\begin{array}{c}\text { DIC } \\
\left(\mathrm{ppm} \mathrm{HCO}_{3}\right)\end{array}$ & $\begin{array}{c}\text { alkalinity } \\
\left(\mathrm{ppm} \mathrm{CaCO}_{3}\right)\end{array}$ & $\begin{array}{c}\text { conductivity } \\
(\mu \mathrm{S} / \mathrm{cm})\end{array}$ & $\mathrm{pH}$ & $\mathrm{T}\left({ }^{\circ} \mathrm{C}\right)$ \\
\hline \multicolumn{11}{|l|}{ Lassen Region } \\
\hline Government Well * & $05 / 94$ & -11.0 & -92 & -12.9 & 115.7 & 188 & - & 290 & - & 19 \\
\hline Hat Creek@ Emigrant Pass & $06 / 95$ & -14.1 & -106 & -7.6 & 72.8 & 25 & 24 & 44 & 7.3 & 4 \\
\hline Hat Creek@ Twin Bridges & $06 / 95$ & -14.0 & - & -3.5 & - & 14 & 18 & 29 & 7.3 & 7 \\
\hline Hat Creek nr. Doyles Corner & $06 / 95$ & -13.8 & - & -5.9 & - & 40 & 45 & 84 & 7.8 & 12 \\
\hline Jelly Spring * & $08 / 94$ & -13.8 & - & - & 111.0 & 154 & 110 & 197 & 6.8 & 12 \\
\hline Kings Creek Spring & $09 / 95$ & -13.8 & -101 & -14.5 & 103.7 & 19 & 14 & 26 & 8.0 & 6 \\
\hline Lost Creek (lower) & $06 / 95$ & -14.1 & -101 & -10.8 & 79.7 & 37 & 32 & 66 & 7.1 & 5 \\
\hline Lost Creek (upper) * & $08 / 94$ & -14.0 & - & +0.4 & 47.8 & 41 & 40 & 93 & 8.0 & 14 \\
\hline Lost Ck. Spring - $1 *$ & $10 / 93$ & -14.3 & -106 & -11.5 & 94.8 & 59 & - & 102 & - & - \\
\hline Lost Ck. Spring $-2 *$ & $02 / 94$ & -14.4 & -103 & -12.3 & 95.8 & 59 & - & 75 & 7.8 & 12 \\
\hline Manzanita Creek & $06 / 95$ & -14.1 & - & - & - & - & - & 85 & 7.2 & 5 \\
\hline Manzanita Lake Spring & $06 / 95$ & -13.7 & - & -12.5 & - & 80 & 45 & 83 & 7.0 & 5 \\
\hline Mill Creek - Hwy 36 & $07 / 95$ & -12.9 & -92 & -5.8 & 89.5 & 15 & 16 & 117 & 5.7 & 12 \\
\hline Moon Springs * & $05 / 94$ & -13.1 & -101 & -11.5 & 116.6 & 51 & - & 82 & - & 18 \\
\hline Mountain Home Spring & $09 / 95$ & -12.9 & -96 & -14.2 & 77.6 & 125 & 52 & 102 & 6.2 & 8 \\
\hline Nanny Creek & $07 / 95$ & -13.2 & -93 & -6.8 & 110.2 & 25 & 25 & 40 & 6.2 & 12 \\
\hline Negro Camp Spring & $06 / 95$ & -14.1 & - & - & - & - & 60 & 92 & 8.5 & 17 \\
\hline Old Boundary Spring - 1 & $06 / 95$ & -14.0 & - & -18.1 & - & 93 & 55 & 106 & 7.2 & 6 \\
\hline Old Boundary Spring - 2 & $07 / 95$ & -14.0 & -99 & -18.7 & 94.3 & 82 & 50 & 102 & 6.5 & 6 \\
\hline Paulson's Well & $10 / 93$ & -13.2 & -94 & -13.4 & 91.1 & 90 & - & 148 & - & - \\
\hline Pole Spring & $06 / 95$ & -14.2 & - & - & - & - & 50 & 91 & 7.3 & 7 \\
\hline Radio Ast. Obsv. Well * & $02 / 94$ & -14.3 & -104 & -15.4 & 107.0 & 73 & - & 90 & 6.7 & 7 \\
\hline Rimrock Well & $09 / 95$ & -13.3 & - & -15.2 & 100.1 & 75 & 70 & 142 & 8.5 & 11 \\
\hline Rising River Sprs - $1 *$ & $10 / 93$ & -13.7 & -101 & -13.6 & 82.6 & 69 & - & 111 & - & - \\
\hline Rising River Sprs $-2 *$ & $02 / 94$ & -14.0 & -100 & -12.1 & 88.3 & 61 & - & 92 & 8.0 & 14 \\
\hline Rising River Sprs - 3 & $02 / 95$ & -13.9 & -100 & -9.1 & 78.8 & 52 & 70 & 125 & 7.3 & 8 \\
\hline Rock Spring $-1 *$ & $02 / 94$ & -14.2 & -104 & -12.7 & 103.0 & 68 & - & 105 & 7.7 & 9 \\
\hline
\end{tabular}


Table 1. Chemical and Isotopic Data

\begin{tabular}{|c|c|c|c|c|c|c|c|c|c|c|}
\hline Sample Location & Date & $\delta^{18} \mathrm{O}$ & $\delta \mathrm{D}$ & $\delta^{13} \mathrm{C}$ & $\begin{array}{l}{ }^{14} \mathrm{C} \\
(\mathrm{pmc})\end{array}$ & $\begin{array}{c}\text { DIC } \\
\left(\mathrm{ppm} \mathrm{HCO}_{3}\right)\end{array}$ & $\begin{array}{c}\text { alkalinity } \\
\left(\mathrm{ppm} \mathrm{CaCO}_{3}\right)\end{array}$ & $\begin{array}{l}\text { conductivity } \\
(\mu \mathrm{S} / \mathrm{cm})\end{array}$ & $\mathrm{pH}$ & $\mathrm{T}\left({ }^{\circ} \mathrm{C}\right)$ \\
\hline \multicolumn{11}{|l|}{ Lassen Region } \\
\hline Rock Spring - $2 *$ & $08 / 94$ & -14.1 & - & -12.5 & 100.0 & 72 & - & 140 & 7.7 & 9 \\
\hline Rock Spring - 3 & $02 / 95$ & -13.5 & - & {$[-10.2]$} & 103.3 & 61 & 80 & 132 & 7.1 & 8 \\
\hline Salmon Springs & $06 / 95$ & -13.6 & - & - & - & - & 60 & 124 & 7.7 & 10 \\
\hline Sam Wolfin Spring * & $05 / 94$ & -13.4 & -99 & -16.6 & 95.2 & 152 & - & 198 & - & 14 \\
\hline Sulphur Creek & $07 / 95$ & -12.3 & - & -7.2 & - & 6 & $<10$ & 181 & 4.8 & 9 \\
\hline Ward Spring & $06 / 95$ & -13.8 & - & - & - & - & 85 & 162 & 7.6 & 11 \\
\hline Wilcox Spring & $06 / 95$ & -13.2 & - & - & - & - & $<10$ & 14 & 7.8 & 9 \\
\hline Willow Spring & 09/95 & -13.1 & - & - & - & - & 12 & 31 & 5.7 & 8 \\
\hline Wilson Meadow Spring & 09/95 & -12.9 & - & - & - & - & - & 81 & 6.3 & 9 \\
\hline \multicolumn{11}{|l|}{ Medicine Lake Region } \\
\hline Crank Spring & 05/95 & -13.7 & - & - & - & - & 70 & 134 & - & 10 \\
\hline Crystal Spring & 09/95 & -13.7 & -98 & -13.9 & 112.6 & 31 & 20 & 37 & 8.2 & 7 \\
\hline Fall River - $1 *$ & $06 / 94$ & -13.6 & - & -11.8 & 80.5 & 62 & 75 & 138 & 7.9 & 12 \\
\hline Fall River - 2 & $06 / 95$ & -13.3 & -94 & -11.2 & - & 69 & 75 & 147 & 8.3 & 14 \\
\hline Lava Creek - $1 *$ & $06 / 94$ & -13.6 & - & - & 73.1 & 78 & 75 & 155 & 8.6 & 14 \\
\hline Lava Creek - 2 & $06 / 95$ & -13.6 & -98 & -10.8 & - & 78 & 75 & 157 & 8.0 & 12 \\
\hline Harris Spring & 09/95 & -13.4 & - & - & - & - & 45 & 78 & 7.6 & 9 \\
\hline Hopkins Cave - Lava Beds & $05 / 95$ & -13.2 & -99 & - & - & - & - & - & - & - \\
\hline Paynes Spring & 09/95 & -13.8 & - & -19.0 & - & 53 & 30 & 59 & 7.6 & 8 \\
\hline Pit River@ Hwy 299 - $1 *$ & $06 / 94$ & -13.0 & - & -9.2 & 83.7 & 65 & - & 166 & 8.6 & 19 \\
\hline Pit River@ Hwy 299 - 2 & $05 / 95$ & -13.0 & - & -10.3 & 102.3 & 61 & 90 & 145 & 7.2 & 13 \\
\hline Pit River@ Hwy 299-3 & $06 / 95$ & -13.1 & - & -11.2 & 91.7 & 78 & 95 & 153 & 7.8 & 14 \\
\hline Pit River@Pittville & $06 / 95$ & -12.9 & - & -10.8 & - & 76 & 100 & 173 & 6.4 & 17 \\
\hline Schonchin Spring & 09/95 & -13.7 & -97 & -17.4 & 117.7 & 61 & 45 & 90 & 7.9 & 6 \\
\hline Sucker Spring & $06 / 95$ & -13.7 & - & - & - & - & 70 & 155 & 7.7 & 13 \\
\hline
\end{tabular}

* Data previously reported in Rose et al. (1995) 
Table 1. Chemical and Isotopic Data

\begin{tabular}{|c|c|c|c|c|c|c|c|c|c|c|}
\hline Sample Location & Date & $\delta^{18} \mathrm{O}$ & $\delta \mathrm{D}$ & $\delta^{13} \mathrm{C}$ & $\begin{array}{l}{ }^{14} \mathrm{C} \\
(\mathrm{pmc})\end{array}$ & $\begin{array}{c}\text { DIC } \\
\left(\mathrm{ppm} \mathrm{HCO}_{3}\right)\end{array}$ & $\begin{array}{c}\text { alkalinity } \\
\left(\mathrm{ppm} \mathrm{CaCO}_{3}\right)\end{array}$ & $\begin{array}{l}\text { conductivity } \\
(\mu \mathrm{S} / \mathrm{cm})\end{array}$ & $\mathrm{pH}$ & $\mathrm{T}\left({ }^{\circ} \mathrm{C}\right)$ \\
\hline \multicolumn{11}{|l|}{ Mt. Shasta Region } \\
\hline Ash Creek & $10 / 95$ & -14.7 & -103 & -0.2 & 108.9 & 11 & 9 & 19 & 8.2 & 7 \\
\hline Bear Spring & $10 / 95$ & -13.9 & -103 & -18.6 & 112.0 & 43 & 20 & 46 & 7.4 & 5 \\
\hline Big Springs & $10 / 95$ & -13.2 & -90 & -17.4 & 89.9 & 62 & 50 & 100 & 8.0 & 7 \\
\hline McCloud River - 1 & 08/94 & -12.6 & - & -17.6 & 91.6 & 60 & - & 104 & 7.5 & 12 \\
\hline McCloud River - 2 & $06 / 95$ & -12.3 & - & -11.2 & 104.9 & 26 & 32 & 47 & 6.9 & 9 \\
\hline McCloud River - 3 & $10 / 95$ & -12.4 & - & -15.7 & - & 66 & 50 & 99 & 7.8 & 11 \\
\hline Mossbrae Spring & $06 / 95$ & -12.8 & -87 & -14.5 & 70.1 & 68 & 55 & 112 & 7.0 & 11 \\
\hline Red Tank Spring & $09 / 95$ & -13.1 & - & - & - & - & 23 & 63 & 7.6 & 8 \\
\hline Sacramento River - 1 & $08 / 94$ & -13.3 & - & -6.6 & 70.3 & 66 & 75 & 178 & 8.4 & 14 \\
\hline Sacramento River - 2 & $06 / 95$ & -13.4 & - & -6.1 & 95.3 & 49 & 60 & 90 & 6.8 & 12 \\
\hline Sacramento River - 3 & $10 / 95$ & -13.3 & - & -7.3 & - & 76 & 60 & 130 & 7.8 & 12 \\
\hline Shasta Springs & $10 / 95$ & -13.3 & - & -14.5 & - & 69 & 45 & 95 & 6.1 & 8 \\
\hline Shasta Soda Spring & $10 / 95$ & -13.3 & -93 & -11.7 & 1.0 & 3050 & $<10$ & 105 & 4.5 & 9 \\
\hline Sisson Spring & $10 / 95$ & -14.7 & -106 & -13.2 & 50.2 & 63 & 37 & 79 & 6.7 & 8 \\
\hline Warmcastle Soda Spring & $10 / 95$ & -12.9 & -88 & -9.5 & 1.1 & 3076 & 500 & 1248 & 6.0 & 9 \\
\hline
\end{tabular}




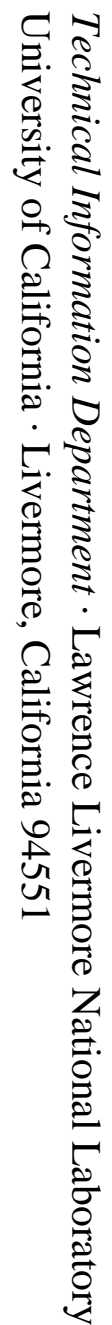

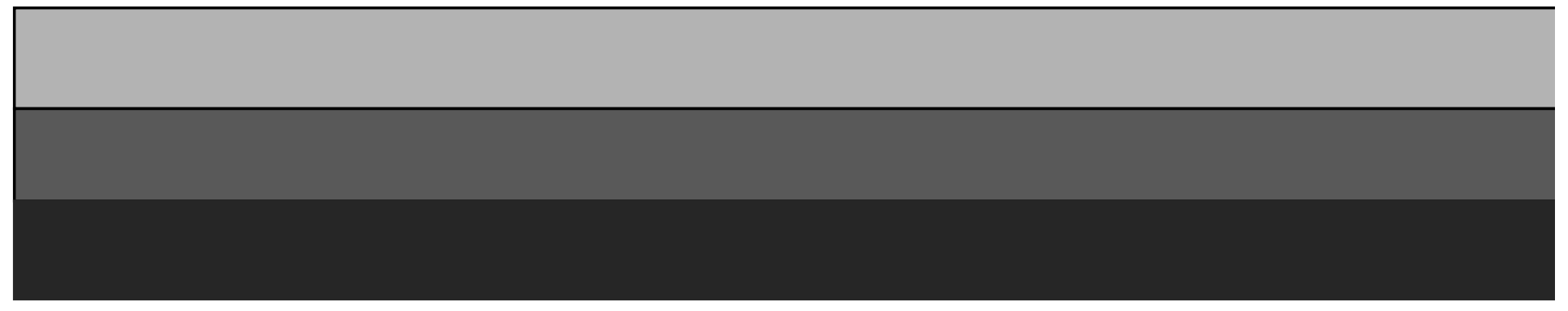

